Abstract: In the stores of the British Museum are three exquisite springs, made in the late $1820 \mathrm{~s}$ and $1830 \mathrm{~s}$, to regulate the most precise timepieces in the world. Barely the thickness of a hair, they are exquisite because they are made entirely of glass. Combining new documentary evidence, funded by the Antiquarian Horological Society, with the first technical analysis of the springs, undertaken in collaboration with the British Museum, the research presented here uncovers their extraordinary significance to the global extension of nineteenth century capitalism through the repeal of the Corn Laws. In the 1830s and 1840s the Astronomer Royal, George Biddell Airy; the Hydrographer to the Admiralty, Francis Beaufort; and the Prime Minister, Sir Robert Peel, collaborated with the virtuoso chronometer-maker, Edward John Dent, to mobilize the specificity of particular forms of glass, the salience of the Glass Tax, and the significance of state standards, as means to reform. These protagonists looked to glass and its properties to transform the fiscal military state into an exquisitely regulated machine with the appearance of automation and the gloss of the free-trade liberal ideal. Surprising but significant connexions, linking Newcastle mobs to tales of Cinderella and the use of small change, demonstrate why historians must attend to materials and how such attention exposes claims to knowledge, the interests behind such claims, and the impact they have had upon the design and architecture of the modern world. Through the pivotal role of glass, this paper reveals the entangled emergence of state and market capitalism, and how the means of production was transformed in vitreous proportions.

\title{
Introduction
}

On Monday 30 May 1853 the post-talk discussion at the Second Extraordinary meeting of the Society of Arts got more than usually nasty. Marine engineer Francis Herbert Wenham had just set out his paper on Constructing Glass Balance Springs for Time Keepers, a method he had developed in the late 1840s in which window glass, heated by a blow-pipe and drawn into a thread, was wound onto a conical mandrel to form a spring, then dropped onto a hot iron bar. On contact, the conical spring would collapse into a flat spiral. Wenham would later note, ' $[\mathrm{u}] \mathrm{p}$ to the time my paper was read I had not the slightest acquaintance with any chronometer maker'. ${ }^{1}$ Poor Mr Wenham had not even begun to describe the advantages of glass over metal springs - less sensitive to temperature, corrosion, and magnetic influence ${ }^{2}$; and, as had been shown in torsion balances in the early 1830 s, capable of more perfect elasticity than the best steel. ${ }^{3}$ Within moments he came under vituperative attack from that notoriously litigious bunch, ${ }^{4}$ not least Benjamin Vulliamy and the

\footnotetext{
${ }^{1}$ Francis Herbert Wenham, 'Letter to the Editor', The Journal of the Society of Arts, Vol. 1, No. 29, (10 June 1853), 337-364, 361.

${ }^{2}$ Second Extraordinary Meeting, The Journal of the Society of Arts, Vol. 1, No. 28, (3 June 1853), 325-336, 326.

${ }^{3}$ William Ritchie, On the Elasticity of Threads of Glass, with some Most Useful Applications of this Property to Torsion Balances, Philosophical Transactions of the Royal Society of London, 120, (18 March 1830), 215-222; and Description and Application of a Torsion Galvanometer, Journal of the Royal Institution of Great Britain, 1, (1830), 29-38.

${ }^{4}$ Francis Beaufort to George Biddell Airy, 30 Nov 1843, Cambridge University Library (CUL), Royal Greenwich Observatory Archives (RGO), Papers of George Airy (6), Chronometer regulations (574), 104-5, ' I object to your making yourself
} 
Frodsham brothers, Charles and George, just a few of the eminent clockmakers in the audience. Wenham found his first foray into the society of horologists, 'peremptorily denounced as one of the puffs of the trade. ${ }^{5}$

Glass springs, said the Frodshams, 'were ingenious, but useless, and not to be mentioned in comparison with those of steel'. If glass was on trial then the experiment should be to make a main spring of glass - the power source; not a balance-spring that acts as a pacemaker. But why bother? Thousands of chronometers had been successful with steel springs and the late great John Roger Arnold had always repudiated any practical utility in using glass. So saying Charles Frodsham took one from his pocket and showed the assembly this exquisite glass spring, (Figure 1). ${ }^{6}$ Made in 1828 by Glasgow watchmaker James Scrymgeour, shown to the celebrated chronometer-maker Edward John Dent at the 1834 Edinburgh meeting of the British Association for the Advancement of Science, where Dent was exhibiting his own glass springs, and passed to Arnold by Scrymgeour in late $1841 .{ }^{7}$ Charles Frodsham had inherited the spring in 1843 , along with Arnold's business, ${ }^{8}$ ten years before he produced it from his pocket at the Society of Arts meeting.

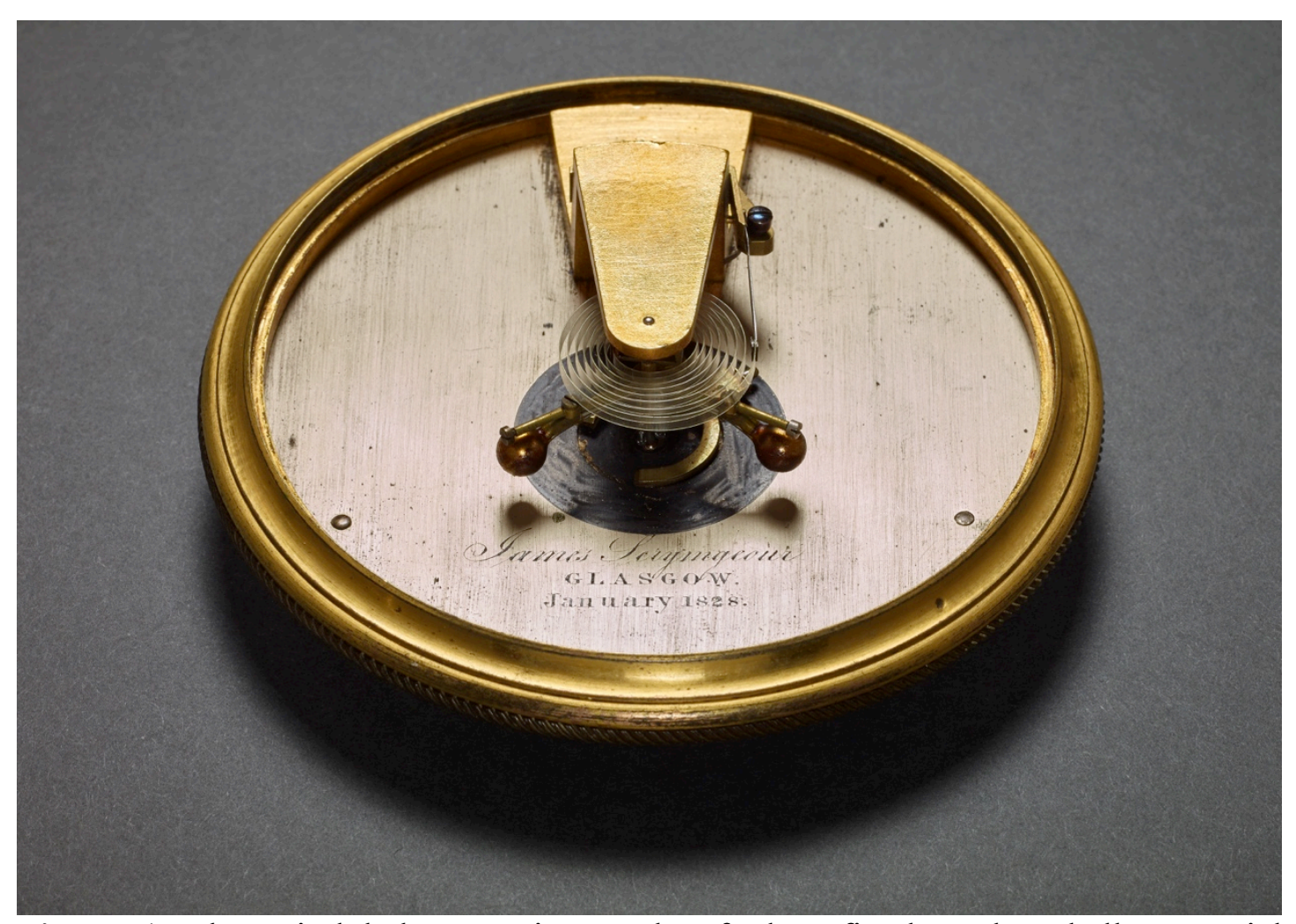

Figure 1. Flat spiral balance-spring made of glass fixed to three-ball mercurial balance. British Museum No. 1958,1006.3073. The Trustees of the British Museum (CC BY-NC-SA 4.0).

too cheap - mixing yourself up with the disputes of these wrangling gentlemen who morally speaking have no right in some of them... all I aimed at was not to let $\mathrm{Mr}$ Airy's good nature expose the Astronomer Royal to the art of litigious people.'

${ }^{5}$ Wenham, 'Letter to the Editor', p.361 (note 1).

${ }^{6}$ Second Extraordinary Meeting, The Journal of the Society of Arts, p.326, (note 2).

${ }^{7}$ James Scrymgeour to George Biddell Airy, 19 January 1850, CUL, RGO 6, Papers on clock and chronometer improvements (589).

${ }^{8}$ Alexander Bridport Becher to George Biddell Airy, 5 June 1843, CUL, RGO 6, Miscellaneous papers on chronometers (595). 
Lawyer, Cambridge wrangler, and clock designer, Edmund Beckett Denison rose to the bait. In 1833, Dent and his future step-son, Frederick Rippon, had used glass to produce a helical balance-spring, fitted in a chronometer now going twenty years and showing remarkable results. ${ }^{9}$ The back-story is well known. Arnold and Dent were then in business together, but the celebrated partnership came to an acrimonious end in $1840 .{ }^{10}$ And three years on, when Arnold died, Dent and Frodsham fought over who would take on his works and contracts. ${ }^{11}$ Following the 1840 dissolution of the partnership, Dent had become involved in the construction of big public clocks, not least the clock for the Royal Exchange, ${ }^{12}$ and in 1852 he won the contract for the construction of the Westminster clock, Big Ben. ${ }^{13}$ Denison was the designer of the New Palace Clock and the two were to work closely together, building on a relationship established as early as July $1845 .{ }^{14}$ Dent died in March 1853 , while Big Ben was under construction, and his collaborator in the 1833 helical glass balancespring, Frederick Rippon, took on both his name and the contract, despite protests from Vulliamy, Frodsham, and the Company of Clockmakers. ${ }^{15}$

When Denison argued with Vulliamy and Frodsham at the Society of Arts, less than two months on from Dent's death, he addressed the meeting as the executor to the will of the recently deceased chronometer maker. Denison spoke on behalf of Dent. ${ }^{16}$ He did not have a glass spring in his pocket as did Frodsham. He pointed instead to the Great Exhibition of 1851, housed in the purpose-built Crystal Palace, and orchestrated by the Society of Arts just a few years previously, in their Great Room, the very room in which they were now assembled. Denison reminded the meeting, as if they could forget, that, in this monumental palace of glass, which made exemplars of choice manufactures of the global economy, Dent's glass balance-spring chronometer had been on display. The debate was now explicitly focused on Dent's work and the audience divided: on the one hand clockmakers ranged against Dent's glass balance-springs, and on the other, designers who spoke for them. ${ }^{17}$ The Frodsham brothers and Denison's respective conclusions are significant, and set out two questions this paper looks to answer. 'Mr George Frodsham said, that if $\mathrm{Mr}$ Dent's experiment had proved successful, it was quite certain he would have made more than one chronometer with the glass spring.' In short, if Dent's glass springs performed so well why was there only one of them? By contrast, 'Mr Denison, on behalf of Mr Dent, said the reason glass springs had not been brought into more

${ }^{9}$ Second Extraordinary Meeting, The Journal of the Society of Arts, pp.326-7 (note 2).

${ }^{10}$ Edward John Dent to George Biddell Airy, 26 December 1840, CUL, RGO 6, 595.

${ }^{11}$ Alexander Bridport Becher to George Biddell Airy, 5 June 1843, CUL, RGO 6, 595.

${ }^{12}$ Edward John Dent to George Biddell Airy, 24 August 1843, CUL, RGO 6, Papers on clock and chronometer improvements (585).

${ }^{13}$ CUL, RGO 6, Correspondence on the New Palace Clock (607).

${ }^{14}$ Edward John Dent to Edmund Beckett Denison, 15 July 1845, Vaudrey Mercer, The Life and Letters of Edward John Dent, (The Antiquarian Horological Society, 1977), 320.

${ }^{15}$ Edmund Beckett Denison, Clocks and Locks, (Edinburgh: Adam and Charles Black, 1857), 112.

${ }^{16}$ Mercer, The Life and Letters, pp.416-9 (note 14).

${ }^{17}$ Second Extraordinary Meeting, The Journal of the Society of Arts, pp. 326-7 (note 2). 
general use, was, that they could not get the workmen to use them.' The springs worked, but the men would not. Further, the statements raise a third question. The documented rates of Dent's glass springs show the springs consistently gained rate, yet Dent and Denison consistently argued for their superior performance. The third question, emerging from the statements of Frodsham and Denison, asks how was it that such gaining rate could constitute superior performance. These three points are worth remembering - why only one spring, why wouldn't the workmen work glass, and how could it be that glass that gained might constitute superior performance. This paper shows that these points are central to understanding the glass springs (Figures $2 \mathrm{a}$ and $2 \mathrm{~b}$ ) in context, and the significance of Dent's glass for innovation, calibration, and standards in the Age of Reform.

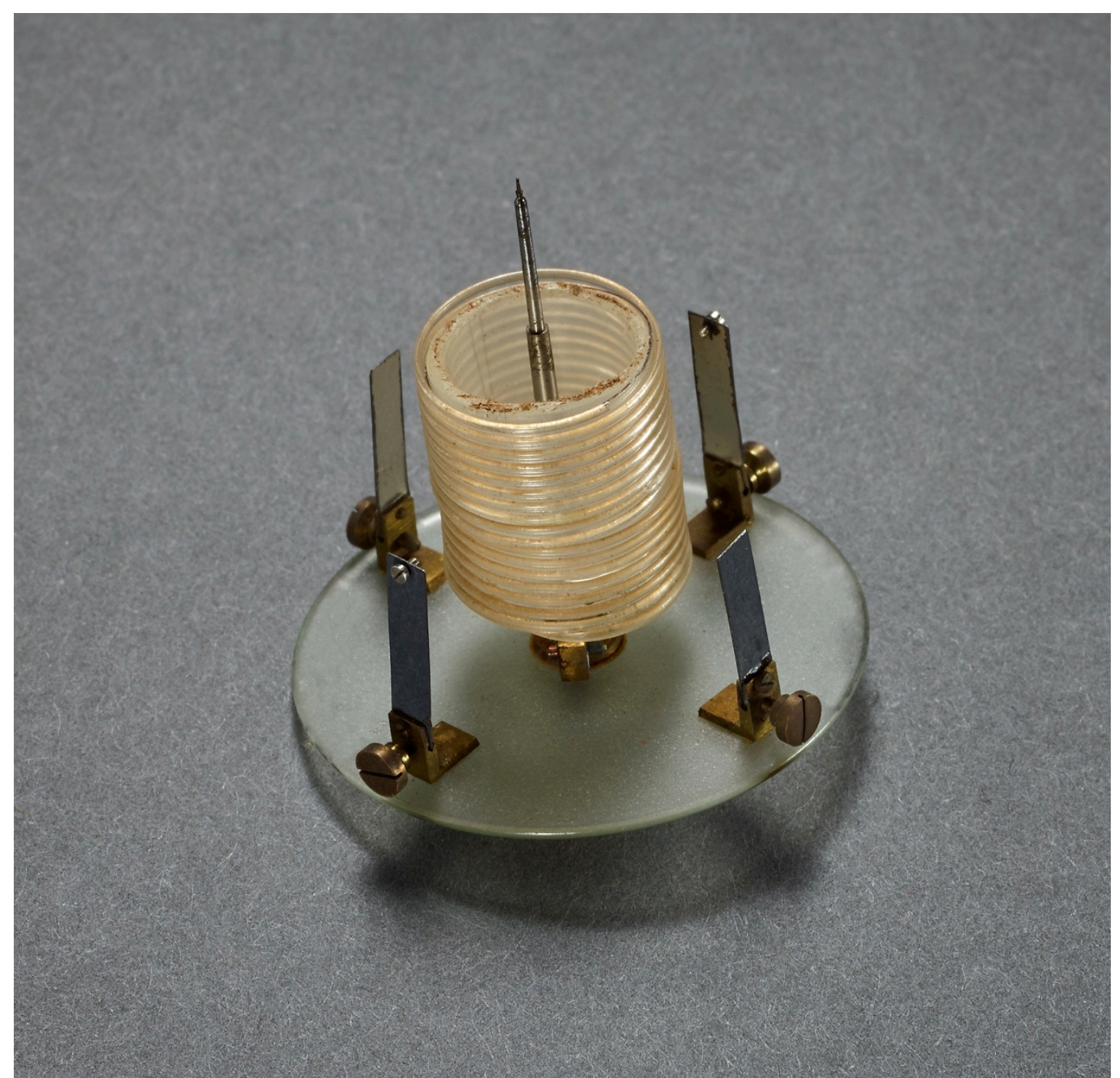

Figure 2(a). Glass balance-spring attached to glass balance disc, dated: 1836, previously incorporated into a chronometer and trialed, British Museum No. 1976,0202.69. The Trustees of the British Museum, (CC BY-NC-SA 4.0). 


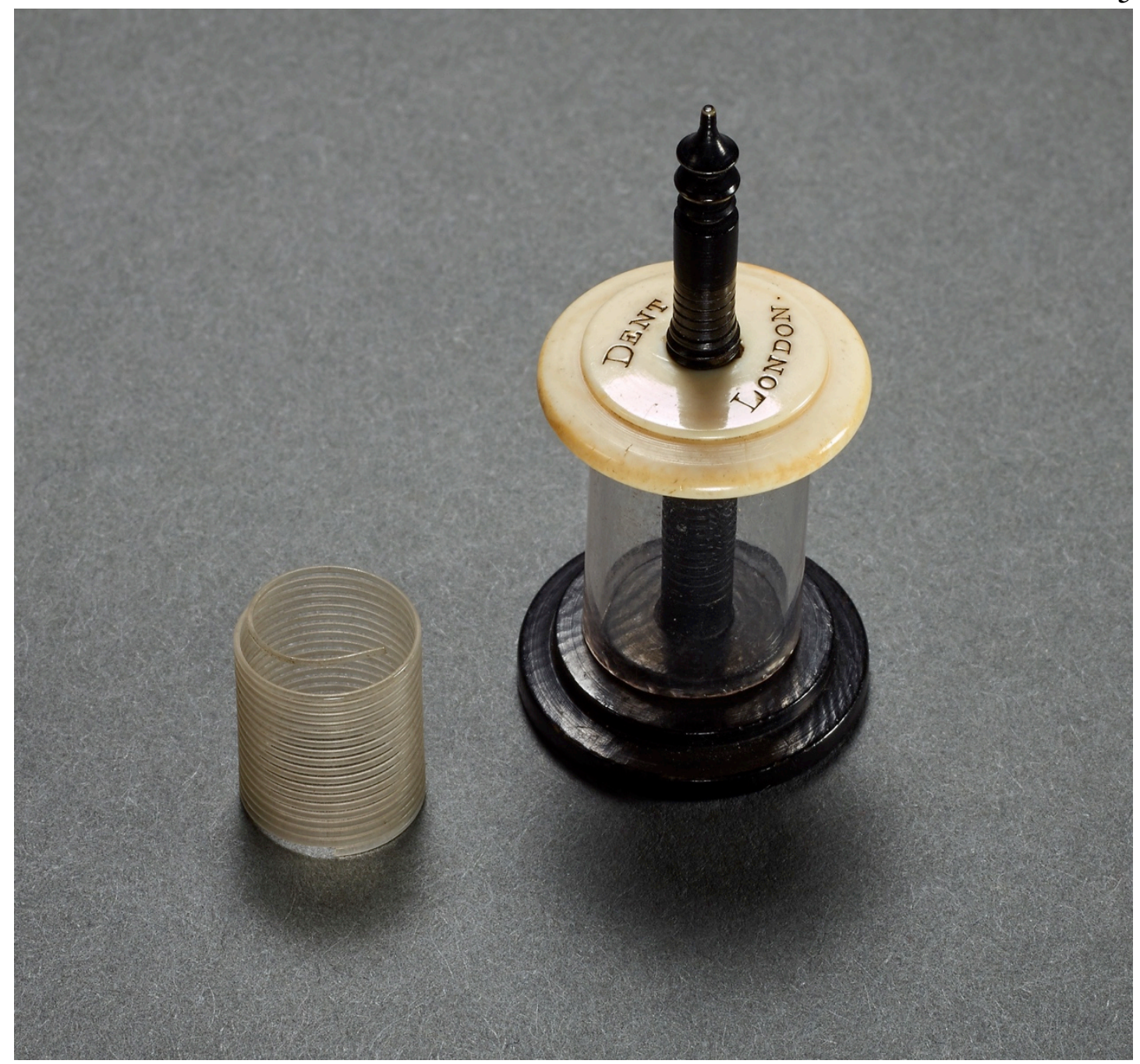

Figure 2(b). Glass balance-spring on ebony stand, dated: 1835-40, displayed but not used in a mechanism, British Museum No. 1958,1006.3009. The Trustees of the British Museum, (CC BY-NC-SA 4.0).

The springs have already received attention from eminent scholars such as Gould, Mercer, and most recently Randall, who provided a brief historical introduction as part of his own exquisite and virtuoso experiments into glass balance springs. ${ }^{18}$ Yet while Randall noted the potential of glass for precision measurement of the effects of temperature, for the most part these works have, like the 1853 meeting, understood the glass springs as an isolated historical curiosity. This paper not only offers the first in-depth analysis of correspondence from the E. Dent Company collection held by Guildhall Library, and the Royal Greenwich Observatory collection held by Cambridge University Library, in particular the Papers of George Biddell Airy. It further develops this documentary study with the very first technical analysis of the composition of the springs, using Variable Pressure Scanning Electron Microscopy, Digital Microscopy, and X-ray fluorescence. This paper offers an example of a programme of research that would take seriously the materiality of the object, and the potential of interdisciplinary collaborative research. The Digital Microscopy of the

${ }^{18}$ Rupert T. Gould, The Marine Chronometer, its history and development, (Admiralty Agent for Charts: London, 1923); Mercer, The Life and Letters, (note 14); Anthony Randall, Glass Balance Springs 1, Horological Journal, (June 2000), 192-5; Glass Balance Springs 2, Horological Journal, (July 2000), 237-40; and Making and Testing Glass Balance Springs, Horological Journal, (February 2009), 56-60. 
two Dent springs shown below (Figure 3(a) and (b) and Figure 4 (a) and (b)), gives an example of the kind of work done. Thanks to these images it is possible to see that the trialled spring, 1976,0202.69, is substantially thicker, and flatter. The significance of this observation is only drawn out in reciprocal relation to the archival study, and will emerge toward the end of the paper. It is crucial for this paper, and the programme of research, that such documentary and artefactual evidence is brought together to produce a fuller understanding than either form of analysis on its own. One method is not taken to be more authoritative than the other, rather it is the creative combination of the two that underpins this paper.

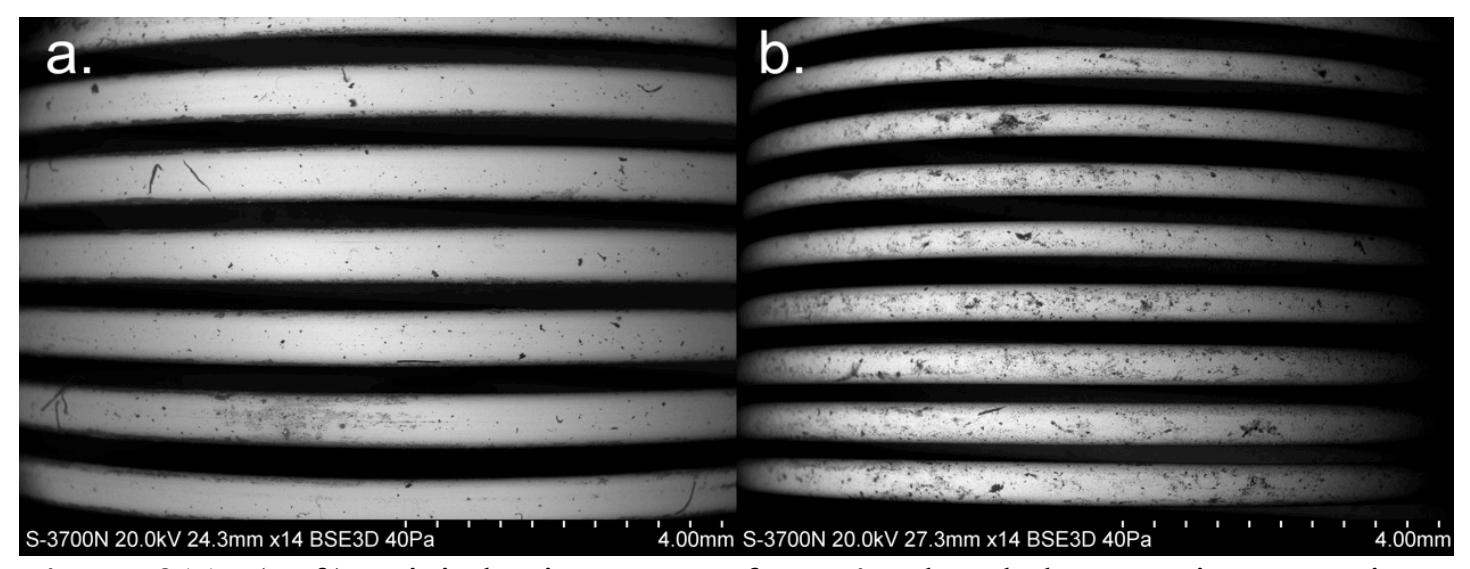

Figure 3(a). (Left). Digital microscopy of Dent's glass balance-spring, see Figure 2(a), British Museum No. 1976,0202.69. The Trustees of the British Museum, (CC Andrew Meek).

Figure 3(b). (Right). Digital microscopy of Dent's glass balance-spring, see Figure 2(b), British Museum No. 1958,1006.3009. The Trustees of the British Museum, (CC Andrew Meek).

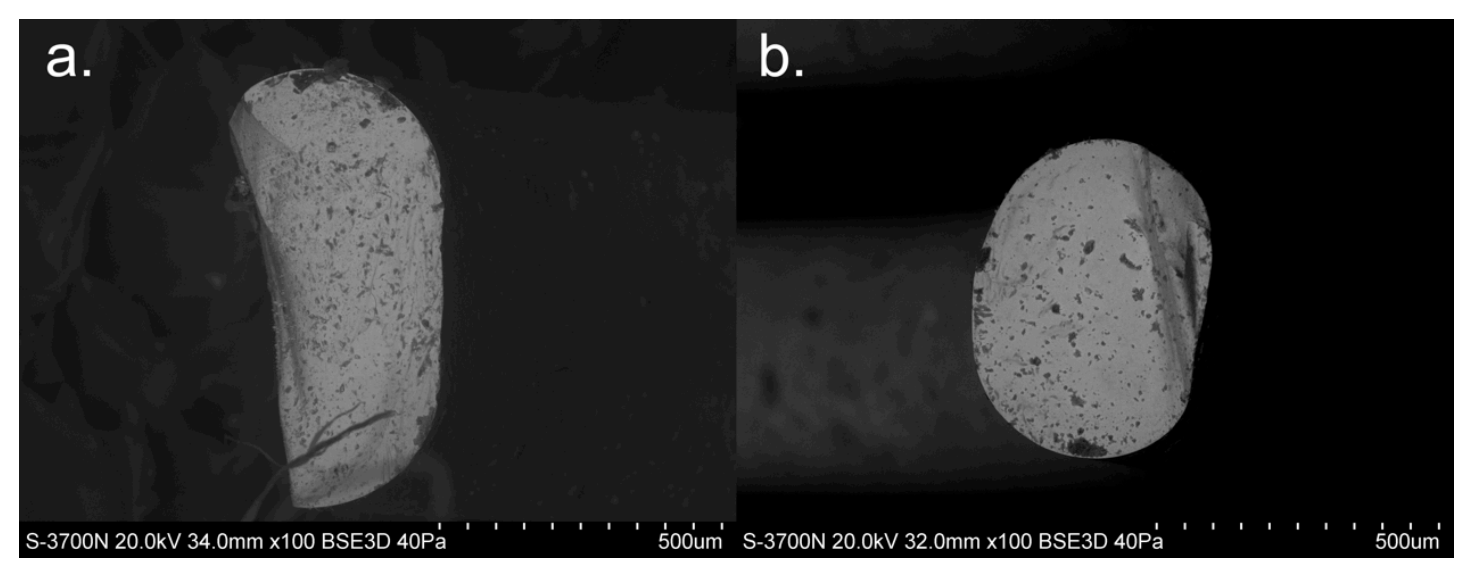

Figure 4(a). (Left). Digital microscopy of Dent's glass balance-spring, see Figure 2(a), British Museum No. 1976,0202.69. The Trustees of the British Museum, (CC Andrew Meek).

Figure 4(b). (Right). Digital microscopy of Dent's glass balance-spring, see Figure 2(b), British Museum No. 1958,1006.3009. The Trustees of the British Museum, (CC Andrew Meek). 
Some brief discussion of the history of glass manufacture in Britain is important here. The glass springs need to be understood in the wider context of industrial organisation and economic and technical innovation at the height of the Industrial Revolution, a time when questions on free trade, whether in corn or glass, iron or labour, were central to the policy of manufacture and the fiscal state. ${ }^{19}$ To understand how and why glass springs might seem singular, and workmen unwilling to deal with these materials, it is first necessary to understand the problem of the glass excise and the history of its relation to the regulation of labour and trade.

There are three aspects to emphasise. First, from its earliest introduction in Britain, glass making was heavily regulated by the state, regulation achieved by constant surveillance, quantification of the raw materials of glass manufacture, ${ }^{20}$ and restriction of the movements and rights of an immigrant workforce trafficked into the country and ghettoised in the glass works. ${ }^{21}$ This provides the second point - the history of the regulation of glass in Britain is a history of social regulation. With the introduction of the window tax at the end of the seventeenth century, glass windows became the "means for the estimation of the ability of the taxpayers to contribute towards the necessities of the state'. ${ }^{22}$ The status of glass goods as subject to duty had long generated regulatory power over production and import. But the declaration, that window glass was a material analogy to property tax, converged with this existing meaning, such that glass not only allowed the state to extend control into private domestic spaces, but it embodied tax. ${ }^{23}$ This is the third and final point - by the eighteenth century, though glass was still a luxury, and just one of several punitively regulated industries in Britain, most notably alcohol, its polysemy was a powerful property. Cognate with a tax on light and life through windows into the home, with the commutation of qualitative value into quantity through the intense surveillance of the state, and with the infamous alcohol tax through the double meaning of glass as drinking vessel, glass and tax became synonyms. It was almost as if glass was tax. 1820 s and 1830 s Britain was in the middle of a glass crisis. ${ }^{24}$ Foreign imports of quality glass increasingly threatened Britain's market leadership. For those vocally

${ }^{19}$ Edward P. Thompson, Customs in Common, (London: Merlin Press, 1991); Boyd Hilton, Corn, Cash, Commerce: The Economic Policies of the Tory Government, (Oxford: Oxford University Press, 1977); Owen Chadwick, The Victorian Church, (London: A. \& C. Black, 1967).

${ }^{20}$ Commissioners of the Excise, Thirteenth report of the commissioners of inquiry into the excise establishment and into management and collection of the excise revenue throughout the United Kingdom: Glass, (London: William Clowes and Sons, 1835), pp.1-22.

${ }^{21}$ Eleanor Godfrey, The Development Of English Glassmaking, 1560-1640, (Clarendon Press: Oxford, 1975), pp.47-50, 65-74, 94. Anita McConnell, 'A survey of the networks bringing a knowledge of optical glass-working to the London trade' Jenny Bulstrode, (ed), (Cambridge: Whipple Museum, 2016), pp.22-37.

${ }^{22}$ Stephen Dowell, Direct Taxes and Stamp Duties, Vol. III of History of taxation and taxes, $2^{\text {nd }}$ ed, (London: Longmans, Green, and co, 1888), pp.168-77.

${ }^{23}$ William Ashworth, Customs and Excise: Trade, Production, and Consumption in England 1640-1845, (Oxford: Oxford University Press, 2003), pp.254-258; Dowell, Direct Taxes and Stamp Duties, p.153 (note 22).

${ }^{24}$ Myles Jackson, Spectrum of Belief: Joseph von Fraunhofer and the Craft of Precision Optics, (Massachusetts Institute of Technology, 2000), pp.99-108. 
lobbying for free trade, the glass industry was understood as like the corn-market, strangled by regulations.

Introduced in 1746 and intensified in 1812, by the 1830s the glass excise defined the categories of glass and discriminated in these types between common bottle glass, with a low rate of tax, and other glass subject to higher rates. Flint glass, made of silica and a significant proportion of lead, was one of the more heavily taxed, over four times the rate imposed on common bottle. The manufacture of this high lead glass was subject to constant surveillance by excise officers and suffered from the most lengthy and complex systems of weighing, re-weighing, watching, and gauging, of all the types of glass defined by the excise. Of the duties on glass, that imposed upon lead glass was by far the most vocally contested. ${ }^{25}$ From the late sixteenth century the state had used restrictions and privileges to push a shift from wood to coal-burning production. Lead glass was developed as a response to the appalling conditions of the coal burning furnaces. ${ }^{26}$ The heat of these furnaces was such that it maimed the workers tasked with the constant stirring essential to produce homogenous glass. With lead as a flux the working-temperature was lowered, and the properties of the glass transformed. ${ }^{27}$ The tax divided glass into strict classes that enforced severe hierarchies of skill and divisions of labour between different sectors of the trade, allegedly hampering innovation and blocking skill transfer. ${ }^{28}$ Eminent savants such as Sir John Herschel and Sir David Brewster lobbied for the repeal of this duty and in particular the oppressive and unremitting surveillance of glass manufacture. ${ }^{29}$ When celebrated chemist Michael Faraday, under the remit of a joint Board of Longitude and Royal Society committee, began his attempts to reverse engineer fine German glass in 1824 , he was frustrated by exactly these questions of geography and material and social organisation in the glass trade. ${ }^{30}$

${ }^{25}$ Commissioners of the Excise, Thirteenth report, pp.1-22 (note 20); David Brewster, 'Some Account of the Late M. Guinand, and of the Important Discovery Made by Him in the Manufacture of Flint Glass for Large Telescopes.' Edinburgh Journal of Science, 2, (1825), 348-354, p.348; and 'Memoir of the Life of M. Le Chevalier Fraunhofer, the Celebrated Improver of the Achromatic Telescope and Member of the Academy of Sciences at Munich.' Edinburgh Journal of Science 7, (1827), 1-11, pp.10-11. Quotation reprinted in David Brewster, 'The Decline of Science in England and the Patent Laws.' Quarterly Review 43, (1830), 305-342.

${ }^{26}$ Godfrey, The Development Of English Glassmaking, pp.47-50, 65-74, 94, (note 21); McConnell, A survey of the networks, pp.26-37, (note 21).

27 Jackson, Spectrum of Belief, p.101, (note 24).

${ }^{28}$ Commissioners of the Excise, Thirteenth report pp.1-22 (note 20); Jackson, Spectrum of Belief, p.100-9 (note 24).

${ }^{29}$ Commissioners of the Excise, Thirteenth report, pp.1-22 (note 20). Brewster, 'Some Account of the Late M. Guinand' p.348 (note 25); Brewster, 'Memoir of the Life of M. Le Chevalier Fraunhofer' pp.10-11 (note 25).

${ }^{30}$ Jackson, Spectrum of Belief, pp. 143-70 (note 24). 


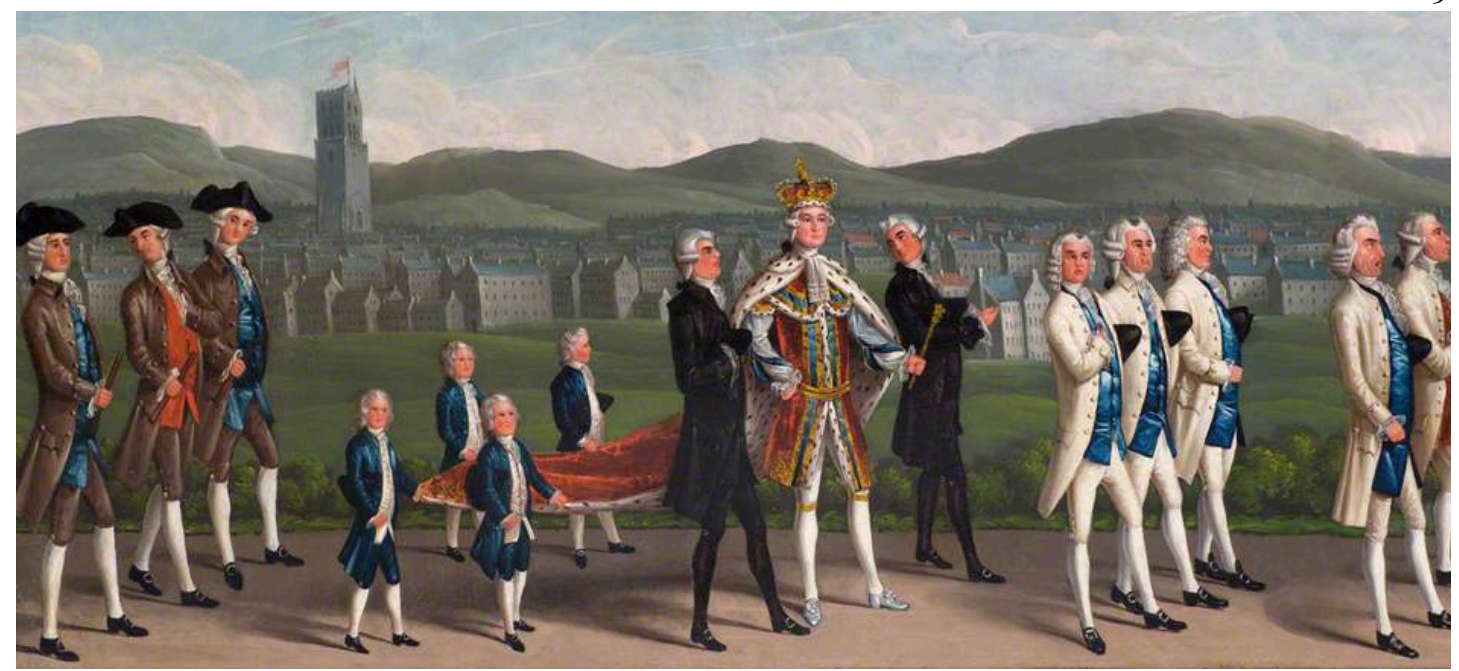

Figure 5. Detail of an $11 \mathrm{ft}$ frieze of King Crispin's Procession formerly in the Cordiner's Room of Dundee City Trade Hall. The frieze was started in 1787 by house painter, Alexander Methuen, and not completed until 1825, by a different house painter, Harry Harwood. ${ }^{31}$ Dundee Art Galleries and Museums Collection, (Dundee City Council).

A couple of episodes from early modern Britain's glass making capital, the coalbased city of Newcastle, are particularly informative in understanding the geography and concomitant social and technical culture of British glass manufacture. They set up an important theme for this paper through the relationship between glass, tax, and innovation. From the fourteenth century Newcastle was run by an effective oligarchy of merchant guilds, whose dignitaries occupied all the civic roles. ${ }^{32}$ By the early seventeenth century this merchant elite lived in glass-fronted houses serving the dual purpose of displaying their wares as well as their wealth and power. This power was consolidated with great quasi-religious processions through the town, in which the merchant-aldermen would parade in all their official trappings, and their households assembled in the windowed fronts of the houses to spectate and admire. Pamela Graves describes how '[ $t$ ] he town elite was constituted by parading in front of others; others were constituted as followers, or even outsiders, by that exclusion'; and the glass windows were the 'means' for this social classification. ${ }^{33}$ Glass was decisive in the representation of power.

In early November of 1789, 'the cordwainers [cordiners, ie shoemakers] of Newcastle, according to annual custom, made a grand procession through the streets of that town and Gateshead, in honour of King Crispin', their patron saint. ${ }^{34}$ The

${ }^{31}$ Sandra M. Marwick, Sons of Crispin: The St Crispin Lodges of Edinburgh and Scotland (Cambridge: Cambridge Scholars Publishing, 2014), p.54.

${ }^{32}$ Pamela C. Graves, 'Civic ritual, townscape and social identity in seventeenth- and eighteenth century Newcastle upon Tyne' in Susan Lawrence (ed), Archaeologies of the British: Explorations of identity in Great Britain and its colonies 1600-1945, (Routledge: London and New York, 2003), pp.31-54, 34.

${ }^{33}$ Graves, 'Civic ritual' pp.39-41, (note 32).

${ }^{34}$ John Sykes, Local Records: or, Historical Register of Remarkable Events, which have Occurred in Northumberland and Durham, Newcastle-upon-Tyne and Berwickupon-Tweed from the Earliest Period of Authentic Record to the Present Time, Newcastle: John Sykes, (1824), p.177. See also, Adrian Randall, Riotous Assemblies: Popular Protest in Hanoverian England, (Oxford University Press, 2007), pp.44-68. 
frieze in Figure 5 shows one such procession that took place in Dundee almost at the same time as the Newcastle event, with a Cordiner dressed as a King to honour Crispin and express the guild's power. Just a week later, and in direct response, the glassmakers of Newcastle also processed, but rather than the formal show of power by the elected elite, the march of the glass makers 'satyrised [sic] the cordiners with the most irresistibly comic humour'. ${ }^{35}$ It was carnival, the subversion of the social order through the performance of the grotesque, and it got so out of hand, so unruly and outrageous, that processions were discontinued for over three decades. Then in 1823, for the first time since the 1789 outrages, the cordiners marched once again through Newcastle. ${ }^{36}$

${ }^{35}$ Sykes, Local records, p.345 (note 34 ).

${ }^{36}$ Sykes, Local records, p.343-4 (note 34). 


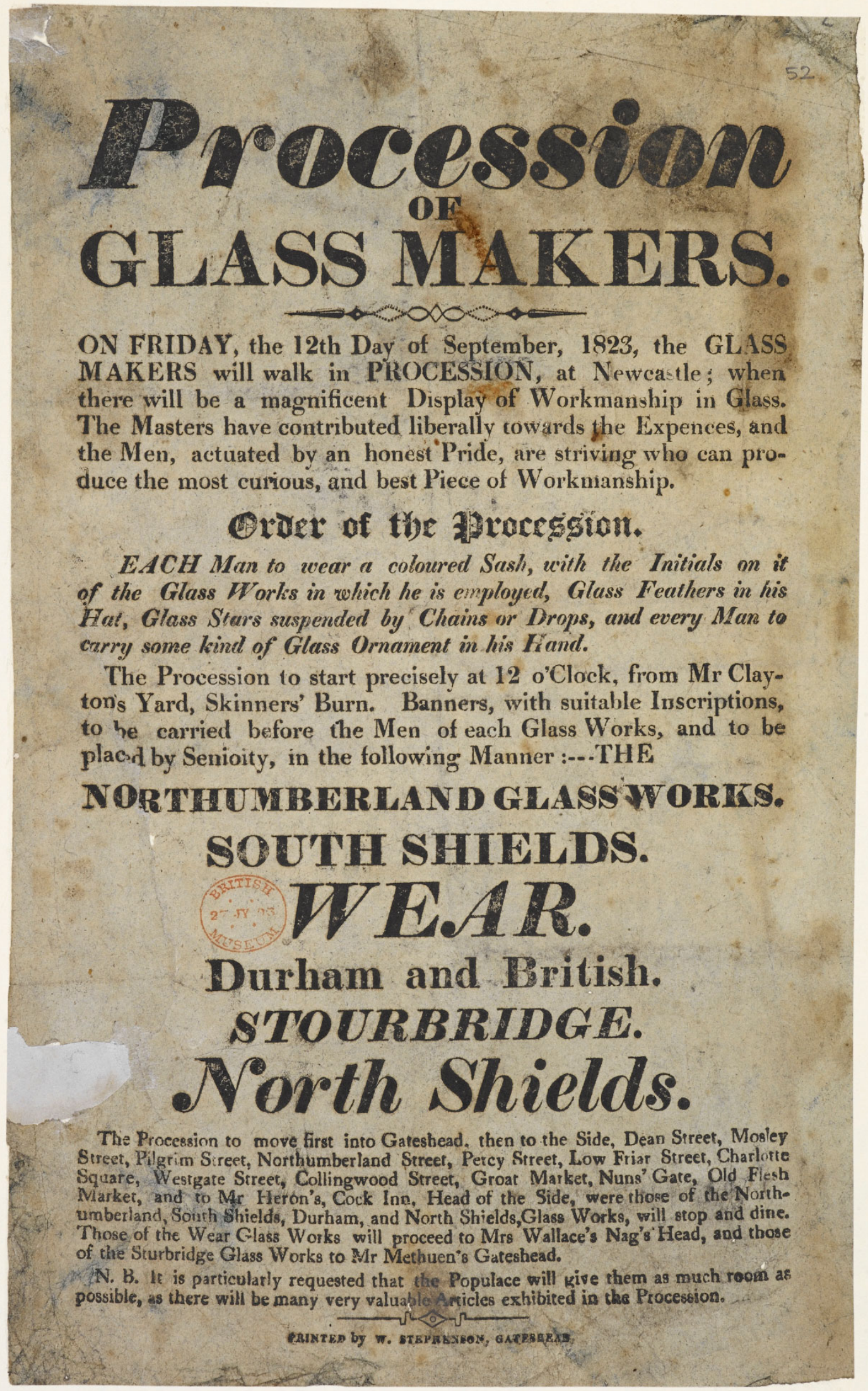

Figure 6: Invitation from Masters of the Newcastle Glasshouses, to the glassmakers, to march in procession, Gateshead, Tyne and Wear, (1823), British Library 74/1881.d.8(52). Public Domain Mark 1.0. 
The glass makers again responded, but in a carefully ordered affair this time with the masters of the glass houses inviting their men to march with their best and most curious pieces of workmanship (Figure 6). ${ }^{37}$ The men responded by making the trappings of the cordiners' march - the swords, bugles, feathers, hats, and badges of office - entirely out of glass (Figure 7). Even the cannons fired to mark the intervals of the procession, were glass cannon. ${ }^{38}$

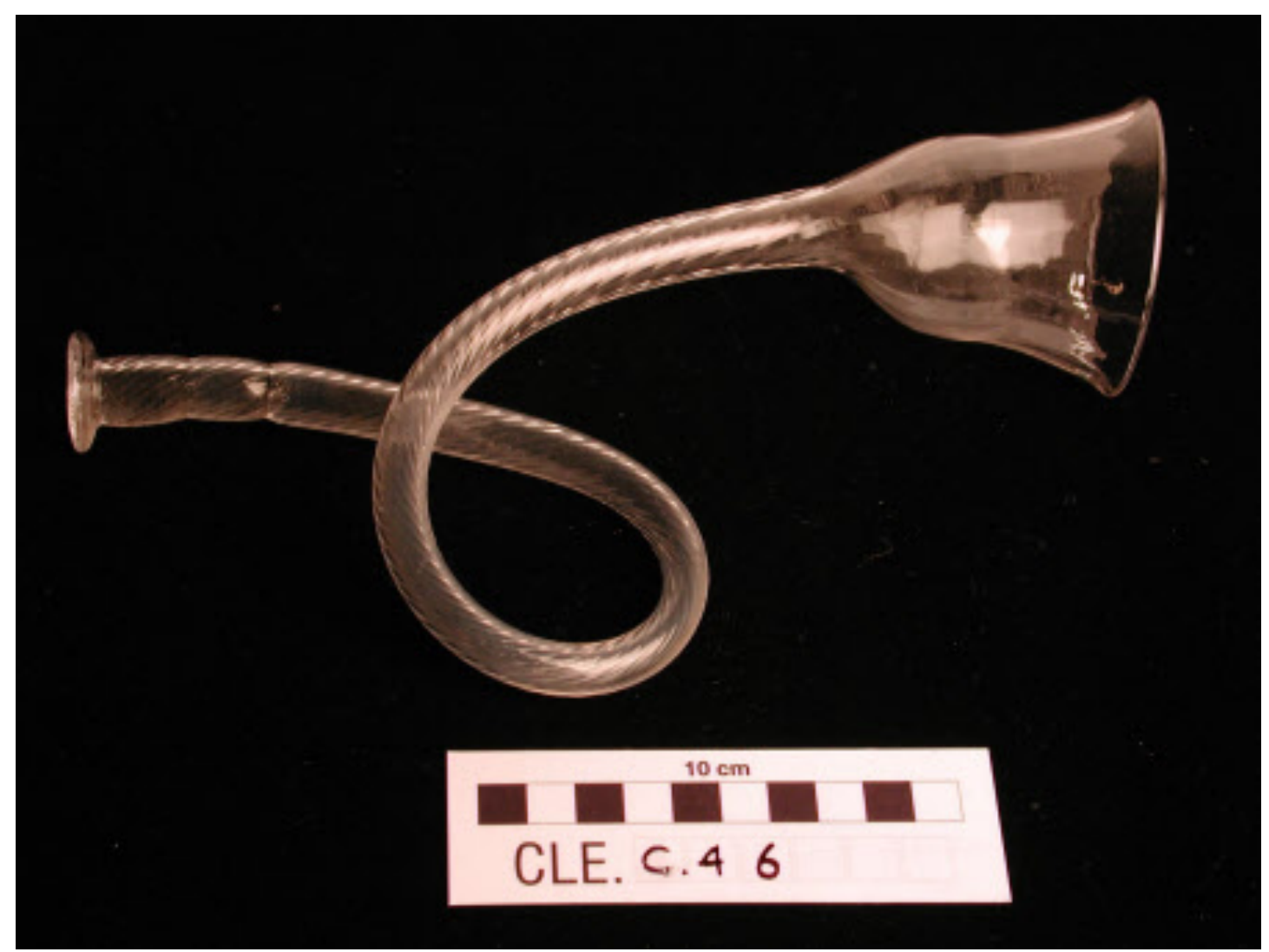

Figure 7: Clear glass wrythen bugle with bell-shaped bowl. Edinburgh Museum and National Trust Collections both hold glass hats, bugles, and swords, sadly no cannon appear to have survived. These are thought to be artefacts from glassmakers' marches, in Newcastle and elsewhere. National Trust Collections, 623407. Copyright National Trust, Seamus McKenna, David Cousins.

Subversion and the carnivalesque affected the furthest reaches of the glass trade. On 31 December 1833, just months after Arnold and Dent first announced that they had successfully applied to the chronometer a balance spring made of glass, ${ }^{39}$ the partners wrote to complain to the then Astronomer Royal, John Pond. Celebrated precision clockmaker, John Sweetman Eiffe, had deposited two chronometers for trial at the Royal Observatory, which, instead of the stipulated numbers, carried the names 'The

\footnotetext{
${ }^{37}$ For the changing nature of riots and popular protest between eighteenth and early nineteenth century see Randall, Riotous Assemblies, pp.303-31, (note 34).

${ }^{38}$ Sykes, Local records, pp.344-5, (note 34). See also William Hone, The Every-day Book and Table book, (London: Thomas Tegg, 1825), pp.1285-6; Eneas Mackenzie, A descriptive and Historical Account of the Town and County of Newcastle, (Newcastle: Mackenzie and Dent, 1827), p.88; William Parson, History, Directory, and Gazetteer, of the Counties of Durham, (Newcastle: White, 1827), p.xlviii

${ }^{39}$ John Roger Arnold \& Edward John Dent, Glass Balance Springs to Chronometers, The Nautical Magazine, (April 1833), pp.222-5.
} 
Glass Fiddle' and 'The Strand and Harlequin'. Writing from their premises on the Strand, just a few hundred yards from the most popular pantomime of the season, 'Harlequin \& Cinderella; or the Glass Slipper', '[T] Arnold and Dent 'of the contempt intended towards us'. ${ }^{41}$ Like the Newcastle glassmakers, Eiffe saw innovation in glass as the stuff of satire, and the springs as a part of satirical theatre.

Vast bibliometric analyses have shown that the origin of Cinderella's glass slipper lies in a seventeenth century mix up over the medieval French for heraldic weasel fur. ${ }^{42}$ But more recent work, building on these analyses, has also shown that the Cinderella story underwent a dramatic shift between 1830 and 1850. Early in the 1830 s the slipper that was simply 'glass' became 'elastic glass'. ${ }^{43}$ In the exhibition halls of London, waistcoats and shoes of glass cloth were displayed as the workmanship of 'Cinderella's Crispin'. They were made from threads of 'elastic glass' drawn and wound just as Dent did in the manufacture of his precision chronometer springs. ${ }^{44}$ The Science Museum even have a sample of this glass cloth from the 1840 s. $^{45}$

${ }^{40}$ Playbill of Theatre Royal, Covent-Garden, Drury Lane, announcing The antiquary and Harlequin \& Cinderella, or, The little glass slipper, (London: Printed by E. Macleish, 2 Bow street, 1820), Princeton University Library, TC113 Box 14.

${ }^{41}$ Arnold \& Dent to John Pond, 31 December 1833, CUL, RGO Papers of John Pond (5), Letters from chronometer makers (237) - Chronometer Ledger (238).

${ }^{42}$ Marian Roalfe Cox, Cinderella: Three hundred and forty-five variants, (London: Published for the Folk-Lore Society, 1893), p.506.

${ }^{43}$ Isobel Armstrong, Victorian Glassworlds: Glass Culture and the Imagination 1830-1880, (Oxford University Press, 2008), p.205.

${ }^{44}$ Anon, The Railway Magazine and Annals of Science, (September 1837), p.224; Tenuity of various substances, Mechanics Magazine, Vol. 31, No. 821, (Saturday, 4 May 1839), pp.78-9; Report on an exhibition at The Royal Polytechnic Institution, Civil Engineer and Architect's Journal, Vol 4. (1841), p.57; Glass Cloth Weaving, Civil Engineer and Architect's Journal, Vol 4. (1841), p.251.

45 'Banner screen with fleur-de-lys pattern in glass fibre, c. 1840 ', Science Museum Group Collection, Object Number: 1944-5. 


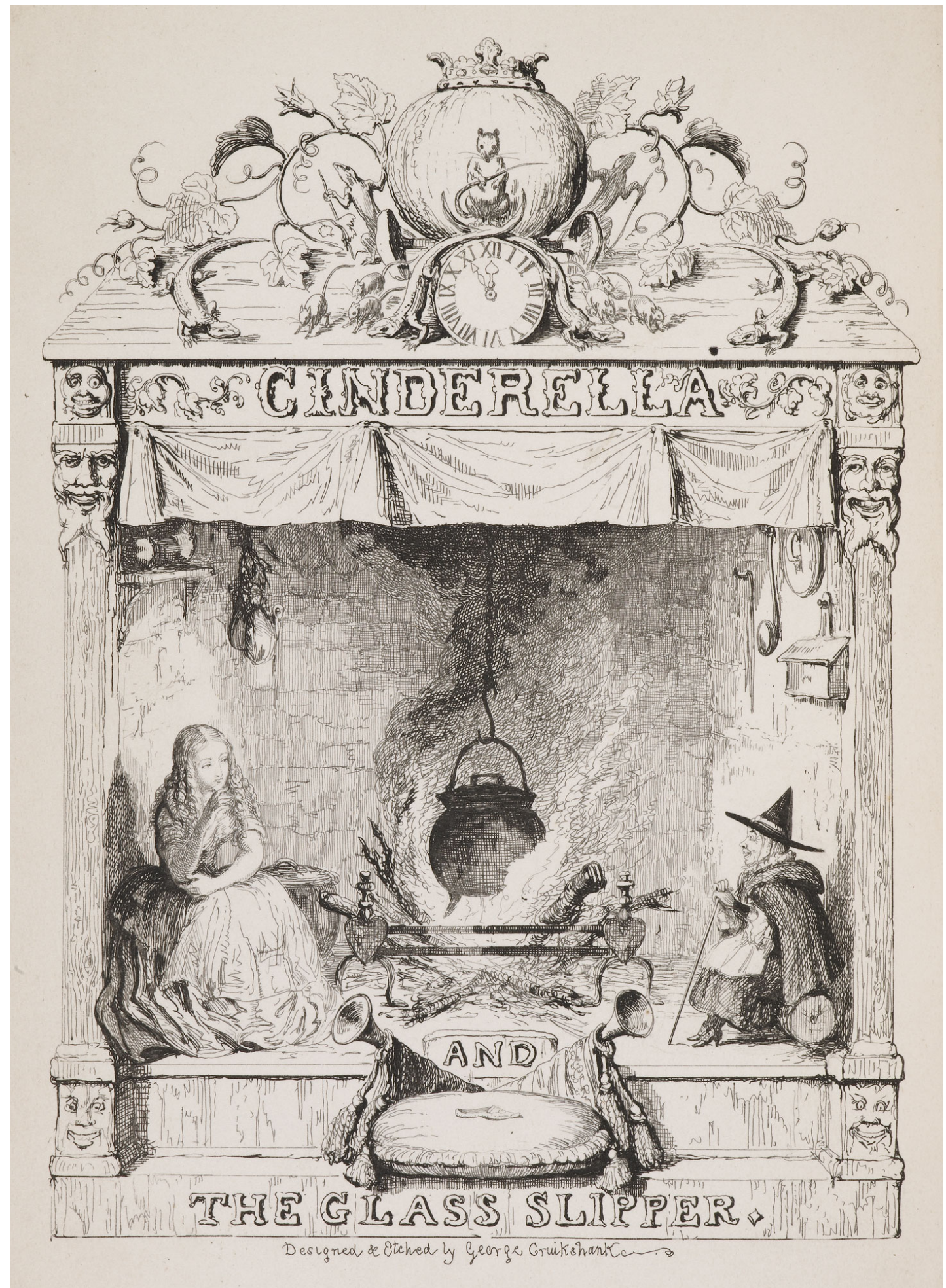

Figure 8. 'Her godmother then took from her pocket a pair of beautiful glass shoes or slippers, and bade Cinderella put them on. Now the soles and lining of these slippers were made of an elastic material, and covered on the outside with delicate spun glass...' Image and excerpt from George Cruikshank's Fairy Library, (London: David Bogue, 1853-4). British Library, C.70.b.9. Public Domain Mark 1.0.

In caricaturist and book illustrator George Cruikshank's Cinderella (Figure 8), her shoes are made of an elastic material and covered in spun glass. The cover illustration (Figure 8) shows Cinderella huddled by the fire, dominated by the face of a public clock top-centre, approaching midnight. It is significant for this paper that by the early decades of the nineteenth century, and above all in Cruikshank's hands, this was 
not just a story about a girl marrying a prince, it was also about labour exploitation, and the role of public clocks in regulating the lives of labourers. Cruikshank's work reflected the contemporary preoccupation with labour relations, often riotous and always fraught in the public extension of time discipline (Figure 9).

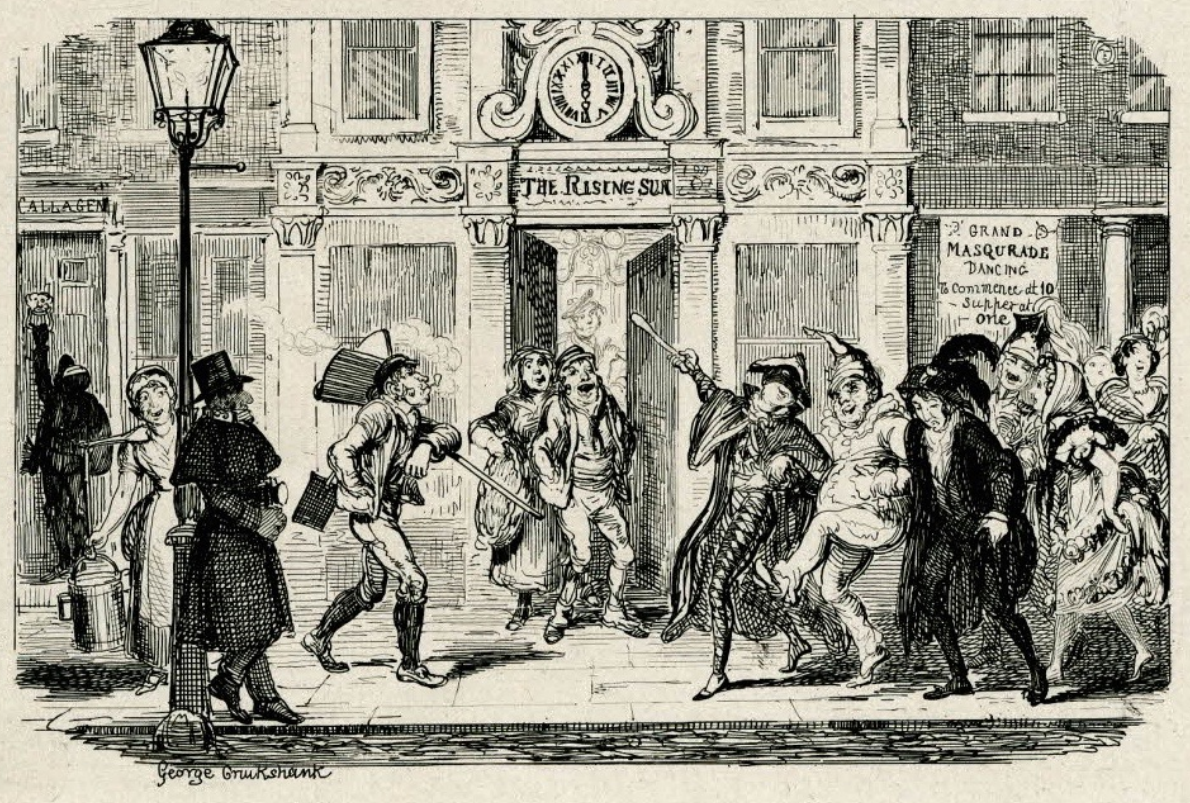

Figure 9. George Cruikshank, 'March - Day and Night nearly equal: Workers meet party-goers at dawn', Comic Almanack, (1836). The Trustees of the British Museum, (CC BY-NC-SA 4.0).

The journalist, Charles Dickens, was infuriated by what he saw as his close friend, Cruikshank's tendency to ruin classic fairy tales with contemporary Victorian moral dilemmas. In his essay 'Frauds on the Fairies', a diatribe against such moralising, Dickens satirised Cruikshank's Cinderella with a Fairy Godmother who first changed mice into horses 'free from the obnoxious and oppressive post-horse duty.' Then, a rat into a 'state-coachman, not amenable to the iniquitous assessed taxes.' Before turning lizards into 'six footmen, each with a petition in his hand ready to present to the Prince, signed by fifty thousand persons, in favour of the early closing movement.' The Fairy Godmother's final act, to 'put on Cinderella's feet a pair of shoes made of glass', was carried out

observing that but for the abolition of the duty on that article, [glass] never could have been devoted to such a purpose; the effect of all such taxes being to cramp invention, and embarrass the producer, to the manifest injury of the consumer.

To Dickens, Cruikshank's Cinderella was, above all, an intervention 'propagating the doctrines of Total Abstinence, Prohibition of the sale of spirituous liquors, Free Trade, and Popular Education'. That Cruikshank used The Glass Slipper to focus concerns quite general to Victorian society; and that Dickens read The Glass Slipper, and heard drink, satire, and tax, is fundamental to understanding the powerful equivocation in glass. ${ }^{46}$

\footnotetext{
${ }^{46}$ Charles Dickens, 'Frauds on the Fairies.' Household Words, No. 184, Vol. VIII. (1
} October 1853), pp. 97-100. 
Glass embodied tax, it was a medium of power and of social regulation, but it was also a medium of social comment through distortion of the existing order. To quote the master of subversive caricature, Jonathan Swift, 'satire was a form of glass'. ${ }^{47}$ Swift referred to the reflection of a mirror, but whether through reflection or refraction this glass mediated observation of the existing order of things; and in the case of the Newcastle glassmakers, it was precisely the drive to satire that led to glass being deployed in such extraordinary, innovative ways, completely counter to habitual classification. It was precisely the polysemic quality of glass, the way in which it could project status, while acting as searing satire on illegitimate status claims, which differentiated it from other highly taxed items, such as beer, in the same move as gesturing to their consumption. Not just the vessel, but also the liquor contained: glass could transform and extend a principle.

In 1846 Prime Minister Sir Robert Peel famously took advantage of just this shift in principle. Addressing the House of Commons, Peel offered his own 1845 abolition of glass duties as the decisive precedent for the 'vivifying' effects on industry that would be brought about by his proposed Corn Law Repeal. He pointed to duty-free glass to show the 'salient spring of prosperity which has supplied the void caused by the remission of taxation', and, 'with that evidence before [him]', argued that '[he] could not, with this conviction, have undertaken the defence of the Corn Laws'. ${ }^{48}$ By the time of Peel's address, the move from abolition of glass excise to repeal of the Corn Laws was well established in literature on the national budget. Just months after the abolition of glass duties, the Unitarian minister Philip Harwood published in the monthly periodical, Tait's Edinburgh Magazine, '[t] he abolition of the cotton import duty and the glass excise we regard as most valuable commercial reforms...Free production of glass and cotton goods requires, as its counterpart and complement, free purchase of corn and sugar. ${ }^{49}$

\section{Tension in composition}

Controlled regulation mattered to the national economy and to the most intimate workings of each and every timepiece. Arnold and Dent were prompted to glass research by concern over the imperfect state of balance springs. The material of the balance spring affected going rate, causing the chronometer to gain or lose depending on whether the spring was made of gold or soft steel. The problem was reduced by using hardened tempered steel of a couple of years' use, so the tension in the structure had been worked out. However, steel raised other problems, highly susceptible to magnetism and rust. Further to this, and most significantly, Arnold and Dent noted that even the best chronometers when exposed to extremes in temperature, would lose at the maximum and minimum. ${ }^{50}$ The 1833 announcement was not only the public debut of Dent's glass springs, but also the first statement of middle temperature error to appear in print. The firm's substitution of glass began as an attempt to do away with the material flaw; and it is compensation for middle temperature error that

\footnotetext{
${ }^{47}$ Jonathan Swift, A tale of a tub: written for the universal improvement of mankind. To which is added, an account of a battle between the antient and modern books in St. James's library, $4^{\text {th }}$ ed, (Dublin, 1705), p. cxxviii.

${ }^{48}$ Sir Robert Peel, 22 January 1845, Hansard Manuscripts, HC Deb, vol 83, cc73-74.

${ }^{49}$ Philip Harwood, The Politics of the Month, Tait's Edinburgh Magazine, (April 1845), p.270.

${ }^{50}$ Arnold \& Dent, 'Glass Balance Springs to Chronometers', pp.222-5.
} 
ultimately explains what happened to the springs. ${ }^{51}$ In July 1833, within months of the first announcement, Arnold and Dent deposited a glass spring chronometer, no. 616, at the Royal Observatory for trial, 'it is worthy to remark' noted Dent, 'that the improvement of the balance has followed that of its spring' ${ }^{52}$ This chronometer had a glass balance as well as balance-spring.

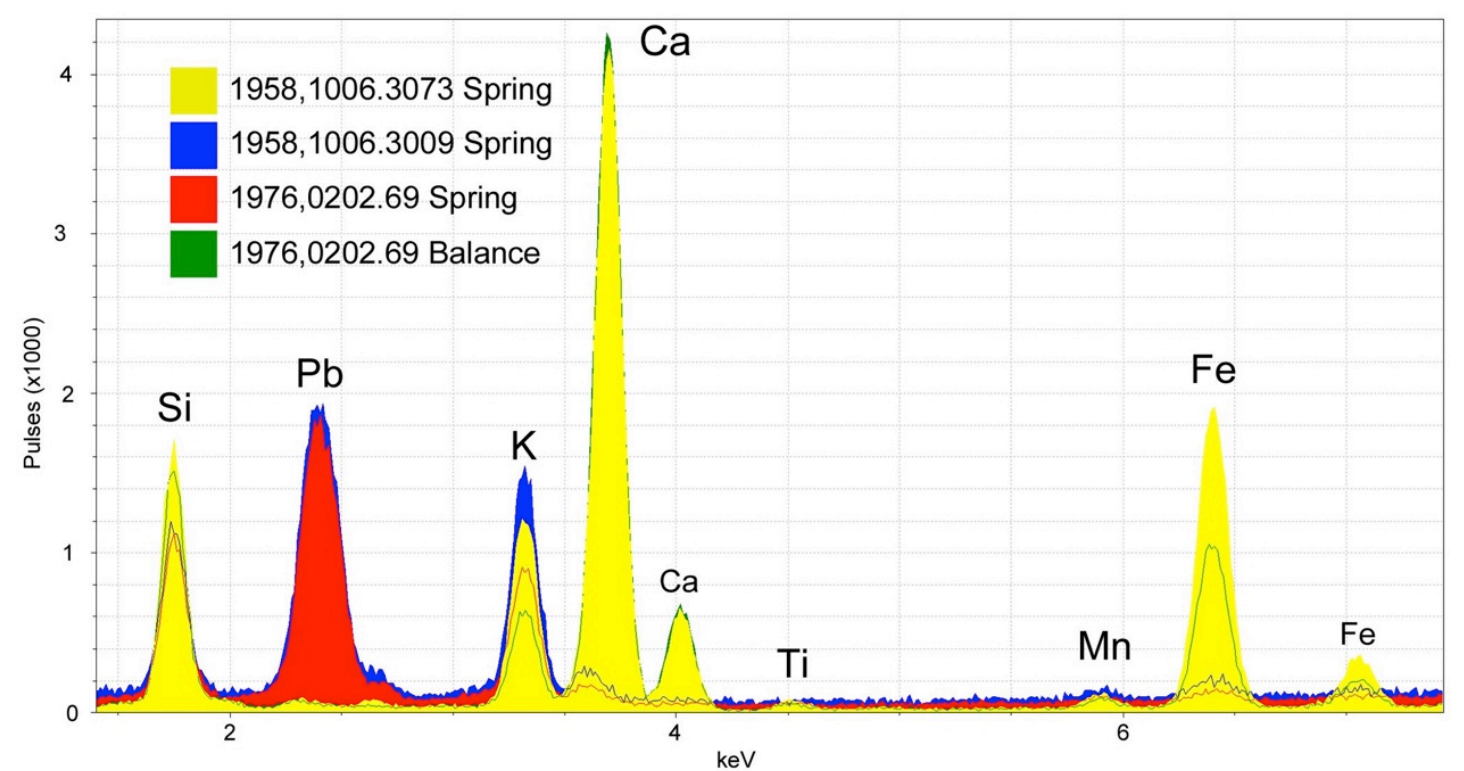

Figure 10. XRF Profiles, AR2017-9 Report, version 1.4. (British Museum Department of Scientific Research, June 2017). The Trustees of the British Museum, (CC Andrew Meek).

Combining documentary evidence with technical analysis of the particular composition of the balance and spring components, we now know Arnold and Dent manufactured the glass of the spring for themselves, ${ }^{53}$ and from purified synthetic materials quite distinct from the common window glass of the time. ${ }^{54}$ The composition of the Scrymgeour flat spiral, indicated by the yellow trace on Figure 10, shows significant levels of silica ( $\mathrm{Si}$, Silicon), lime (Ca, Calcium) and potash (K, Potassium); and, it is important to note, no lead ( $\mathrm{Pb})$. Further analyses also found high strontium levels, indicative of a seaweed base like Kelp. This trace corresponds with 1830s 'Kelp glass', widely used for windows and one of the dominant compositional types the time, ${ }^{55}$ as such the results for the analysis of the Scrymgeour flat spiral serve as a useful comparison with the analyses of Dent's springs and balance. The red trace refers to the thicker and flatter Dent spring that was trialled, 1976,0202.69; while the blue trace refers to the rounder, finer spring that was only ever displayed, 1958,1006, 3009. It is evident both Dent springs are of an entirely

${ }^{51}$ Edward Dent to George Biddell Airy, 12 October 1843, CUL RGO 6587 and Airy's annotations on copy of 'Glass Balance Springs to Chronometers' in CUL RGO 6587.

52 Arnold \& Dent, 'Experimental Chronometers', Nautical Magazine, (July 1833), pp.417-8, 417.

${ }_{53}$ Arnold \& Dent, 'Experimental Chronometers', p.417.

${ }^{54}$ Andrew Meek, AR2017-9 Report, version 1.4. (British Museum Department of Scientific Research, June 2017).

${ }^{55}$ Meek, AR2017-9 Report, (note 42), comparison with David Dungworth, 'Historic Window Glass. The use of chemical analysis to date manufacture' Journal of Architectural Conservation, 18, (2012). pp. 7-25. 
different composition to the Scrymgeour spring; and almost identical to one another. The one discrepancy - the potassium $(\mathrm{K})$ spike found on the blue trace for the rounder, finer 1958,1006, 3009 - is correspondent with surface dirt, residue from handling, the significance of which will be return in the conclusion of this paper. By contrast to the results for the Scrymgeour spring, the analysis of the Dent springs shows them to be made from extremely pure synthetically produced raw materials: saltpetre, quartz, and, significantly, really high lead.

From his earliest glass researches, Dent's overwhelming priority was the specific material composition of the glass. ${ }^{56}$ Having identified the potential of the glass substitution for the performance of balance components, it was, above all, the relation of the particular glass composition to the category of glass tax, and the apparent restriction on technical innovation that this tax imposed, which preoccupied the eminent chronometer maker. When, in July 1833, Arnold and Dent wrote to the Editor of the monthly periodical for seafarers, The Nautical Magazine, on the importance of the construction of the balance spring for chronometers, their statement that '[i]n our opinion, nothing demands the attention of the chemist more than the production of glass, which shall, if possible, be entirely free from lead', ${ }^{57}$ was a direct reference to Faraday's chemical researches on behalf of the Glass Commission. As already noted, this Commission was the most vocal lobby for the repeal of the glass tax. ${ }^{58}$ From their debut Dent treated his glass researches as an intervention in contemporary debates calling for the deregulation of glass. ${ }^{59}$ These interventions, it will be shown in the third section, 'The springs on trial', extended to the campaign for free trade and the repeal of the Corn Laws. The history of glass manufacture already outlined clearly illustrated the polemical and polysemic status of this vitreous material in Britain. When Dent announced his glass researches, and subsequently toured his springs the length of Britain, he showed them as a representatives, standing on behalf of material innovation, and offering to correct past errors. ${ }^{60}$ From the first they were introduced as a kind of reforming standard.

Crucial to understanding Dent's glass researches, and their role in the campaign for free trade and the repeal of the Corn Laws, the composition of Dent's glass balance, shown by the green trace, is completely different from either of his springs (Figure 10). It does not have the lead $(\mathrm{Pb})$ spike seen on the blue and red traces, it is, in fact, closer to the yellow Scrymgeour trace. High in Strontium, made entirely without lead, it is another kelp glass, an entirely different category of the glass excise, and a different and very particular significance in the history of British standards. Lead glass was associated with the meticulous quantification of its constituent materials by excise officers, and a tariff that transformed these cheap, readily available raw

56 John Roger Arnold \& Edward John Dent, 'Glass Balance Springs to Chronometers', p.224, (note 39); Messrs Arnold \& Dent, communicated by Francis Beaufort, read 12 May 1836, On the Application of Glass as a Substitute for Metal Balance Springs in Chronometers, GB 117 The Royal Society, AP/20/3.

${ }^{57}$ John RogerArnold \& Edward John Dent, 'Experimental Chronometers', p.417, (note 52).

${ }^{58}$ Jackson, Spectrum of Belief, pp.143-70, (note 24), Commissioners of the Excise, Thirteenth report, pp.1-22, (note 20).

59 John Roger Arnold \& Edward John Dent, 'Glass Balance Springs to Chronometers', p.224, (note 39).

${ }^{60}$ John Roger Arnold \& Edward John Dent, 'Experimental Chronometers', p.417, (note 52). 
materials into a high value form like gold. By contrast window glass such as that used by Scrymgeour and for Dent's balance carried a much lower rate of tax on the material, but was notorious as the means by which officers could indirectly tax the personal wealth of the individual. Lead glass was the salient embodiment of quantification, while window glass was the silent means by which the state extended into the private domestic space, and commuted qualitative wealth into discrete quantities. $^{61}$

\section{The springs on trial}

While No. 616 was trialled at the Royal Observatory, a second, no. 790, was trialled on ship, on a survey of the North Sea, and Dent toured the country from London to Cambridge and Edinburgh, using working models to show the springs in motion. ${ }^{62}$ In March 1836, three years on from the first deposit of the glass spring chronometer at the Observatory, the Hydrographer to the Admiralty, Francis Beaufort, wrote to the recently appointed Astronomer Royal, George Biddell Airy, noting that Dent had applied to continue the rating of the Glass Spring Chronometers; that, '[a]s far as they have gone these experiments have been highly interesting' and added, 'I wish you would turn your powerful mind for a few minutes to the subject - for it is evidently in the $\wedge$ balance and balance spring that we must now look for essential improvement in all Chrono. ${ }^{63}$ Over the next few months the results of the glass springs' performance came under close scrutiny. It quickly emerged 'that it was formerly not usual to register the temperatures in the Chronometer room except during the Annual public trials'. ${ }^{64}$ The impact of Dent's glass researches on these trials was striking.

A competitive premium system by which the Admiralty maintained its contracts, the annual public trials had been established in 1822 to promote the number and improvement of chronometers in use by the Navy. By guaranteeing to purchase the trialled chronometers that kept best time at a protected price, $£ 300$ for the best, $£ 200$ for the second best, the trials defined technical and market standards for British chronometry. ${ }^{65}$ It was in this capacity that they became the focus of intense public interest. Following an order of January 1835 the public trials were 'terminated' in 1836, the Lords Commissioners of the Admiralty '...satisfied that the intention with which the system of Annual Trials of Chronometers and pecuniary premiums, was established at the Royal Observatory, has now had its full effect' ${ }^{66}$ Far from an end to trials, this 'termination' saw the public spectacle formally institutionalised in the

${ }^{61}$ Dowell, Direct Taxes and Stamp Duties, pp.168-77, (note 22).

${ }^{62}$ Report of the Third Meeting of the British Association for the Advancement of Science held in Cambridge in 1833, (London: John Murray, Albemarle Street, 1834), pp.421, 483; Institutions of Civil Engineers, The Athenaeum, 295, (1833), pp.403404; Royal Institution. The Athenaeum, 330, (1834), p.145; Fourth Meeting Of The British Association For The Advancement Of Science, The Athenaeum, 360, (1834), pp.694-699; Royal Society, The Athenaeum, 458, (1836), pp. 554-555; Eighth Meeting Of The British Association For The Advancement Of Science, The Athenaeum, 566, (1838), pp.619-637; Eleventh Meeting Of The British Association For The Advancement Of Science, The Athenaeum, 722, (1841), pp.668-679.

${ }^{63}$ Francis Beaufort to George Biddell Airy, 2 March 1836, CUL RGO 6585.

${ }^{64}$ Robert Main to Francis Beaufort, 4 May 1836, CUL RGO 6585.

${ }^{65}$ John Wilson Croker, Letter from the Admiralty Office, London Gazette, (26 June 1821), 1351-2, p.1351.

${ }^{66}$ John Barrow, to John Pond, 10 January 1835, CUL RGO 6574. 
working of the Observatory. It marked the inauguration of the Royal Observatory as the site of regulation of public time standards in Britain, and with it the power of Admiralty contracts to define technical and market standards: the official rate.

Airy took up his appointment as Astronomer Royal that same year and it was under his management the trials were fully institutionalised. When, a few months later, Dent requested the temperatures for the ratings of the glass spring chronometer deposited at the Observatory, he had a significant impact on the nascent institution. From that point on, all trials would take place alongside constant temperature observations. In August 1841, speaking at the eleventh meeting of the British Association, held in Plymouth, Dent presented the official rate of the glass spring chronometer after five years' trial in the Observatory. ${ }^{67}$ Just three months later, the Hydrographic Office sent notice to chronometer makers that from then on the publication of official rates would be the sole preserve of the Admiralty. Further, and explicitly prompted by the glass spring chronometer trials, it was decreed that,

....in the beginning of 1843 and at all subsequent trials, [chronometers] will be rated at the discretion of the Astronomer Royal through a variety of temperatures, from the lowest that can be obtained without artificial means, up to that of $100^{\circ}$ Fahrenheit. ${ }^{68}$

The role that government trials and Airy's chronometer management played in the regulation of time in Britain is well acknowledged and celebrated in official histories of the Observatory and the Victorian time system. However, the pivotal contribution of Dent's glass researches has remained entirely unmarked. These researches, and the cognate articulation of middle temperature error, a connexion both Dent and Airy would later refer to in priority disputes, played a fundamental role in the institutionalisation of measurement standards.

Despite Beaufort's request, Airy and Dent became absorbed with projects of design, rather than material. The first was a glass-fronted mantelpiece clock for Airy's home that would show all its internal workings, ${ }^{69}$ the second a chronometer with a concealed tell-tale ${ }^{70}$ - an idea carried over from the ruthless techniques of labour discipline in factories. In Charles Babbage's celebrated 1832 work On the economy of machinery and manufactures, seminal in the history of political economy, the mathematician described the factory tell-tale as 'perhaps the most useful contrivance of its kind', designed to ascertain 'the vigilance of the watchman'.

It is a piece of mechanism connected with a clock placed in an apartment to which the watchmen has not access; but he is ordered to pull a string situated in a certain part of his round once in every hour. The instrument, aptly called a tell-tale, informs the owner whether the man has missed any, and what hours during the night. ${ }^{71}$

Airy's career was founded in making such ruthless techniques authoritative and scientific. Though a bitter rival of Babbage, Airy made extensive use of his competitor's work and further based his Cambridge lectures from the late 1820s

\footnotetext{
${ }^{67}$ Eleventh Meeting Of The British Association, The Athenaeum, p.669, (note 62).

${ }^{68}$ Hydrographic Office, 26 November 1841, Notice to Chronometer Makers, CUL RGO 6574.

${ }^{69}$ George Biddell Airy to Edward John Dent, 7 January 1836, CUL RGO 6585.

${ }^{70}$ George Biddell Airy to Francis Beaufort, 24 July 1837, CUL RGO 6585.

${ }^{71}$ Charles Babbage, On the economy of machinery and manufactures, (London: Charles Knight, 1832), p.40.
} 
through the early 1830 s on the exemplary system of labour discipline - the prison treadmill. ${ }^{72}$ Dent and Airy both produced designs for tell-tale rundowns, to be constructed by Dent, to compare their performance. ${ }^{73}$ In private correspondence with Beaufort, Airy noted, 'Now it cannot by denied that the thing ${ }^{\wedge \text { if concealed }}$ is of the nature of a spy, but in the first place it has none of the envy, hatred and bad or selfish passions of a human spy and in the next place it might be employed in the first instance simply to collect evidence... There is my casuistry for you. ${ }^{74}$ Chronometry and factory discipline were united in Airy's moral science. Interest in the glass springs almost seemed to have run down; that is, until 1840 when the partnership between Arnold and Dent was irrevocably broken. Seceded from the partnership, Dent set up a factory as an independent industrialist.

Dent's change in circumstances is crucial to understanding the fate of the glass springs. The clock-making trade was intricately distributed, broken up into the skills of specialist trades scattered across the city. ${ }^{75}$ Just as the 1820 s glass crisis was all about regulation of trade and control of foreign imports, so was Dent's centralisation of notoriously distributed chronometric capital in a single manufactory. There was an intrinsic relationship between the high cost of labour; of food, via the Corn Laws; and of state excise. For Dent, now an independent industrialist, political economy provided a means to reorganise this relationship to his advantage, through the division of labour.

\section{Metrologies, Standards and the Political Economy of Industry}

Following the split with Arnold, Dent acquired a factory at Somerset Wharf and concentrated the separate branches of the clockmaking trade under one roof and one management, his own. ${ }^{76} \mathrm{He}$ was no longer a partner in a joint firm, but an owner of factories and an industrialist with an intense ambition 'to have the best and I believe only complete manufactory of chronometers in London and I may almost say the world'. ${ }^{77}$ In 1833, as a member of the Clockmakers' Company, Dent joined his fellow clockmakers to lobby government demanding heavier import duties on foreign watches 'principally made in Swisserland [sic], a country exempt from Taxes, Rates and Tithes, and without Corn Laws to force up the value of labour. ${ }^{78}$ The lobby already saw the Corn Laws as a disadvantageous force in their war with low wage competitors. In the early 1840 s following the dissolution of his partnership with Arnold, ${ }^{79}$ Dent's target changed: rather than lobbying for heavier duties on imports to

\footnotetext{
${ }^{72}$ Simon Schaffer, 'The Lucasian Professorship 1820-39', in Knox and Noakes (eds) From Newton to Hawking: a history of Cambridge University's Lucasian Professor of Mathematics, (Cambridge University Press, 2003), pp.241-94, 272-3.

${ }^{73}$ George Biddell Airy to Francis Beaufort, 9 August 1837, CUL RGO 6585.

${ }^{74}$ George Biddell Airy to Francis Beaufort, 9 May 1837, CUL RGO 6585.

${ }^{75}$ For this and for further discussion around Table 1, see Eóin Edward Phillips, Making time fit: astronomers, artisans, and the State, 1770-1820, (University of Cambridge Department of History and Philosophy of Science, 2014.

${ }^{76}$ Edward John Dent to George Biddell Airy, 13 September 1843, CUL RGO 6585.

${ }^{77}$ Edward John Dent to Edmund and George Blunt, c. 7 January 1840, Guildhall MS, Copy out-letter books of Edward John Dent, (18010).

${ }^{78}$ A statement of the various proceedings and transactions that have taken place between the Court of Assistants of the Clockmakers' Company of the City of London and His Majesty's Government, (Worshipful Company of Clockmakers, 1833), p.11.

${ }^{79}$ Edward John Dent to George Biddell Airy, 26 December 1840, CUL, RGO 6, 595.
} 
protect domestic industry, he called instead for the repeal of the Corn Laws, deregulation that would in turn justify a drop in wages. He noted that since splitting with Arnold and heading his own works, 'he had made more English watches than at any prior period, and consequently have paid more for labour' ${ }^{80}$ For Dent his time keepers could out-compete foreign manufactures specifically because they were painstakingly compensated for variable temperature, and so vastly superior. But this compensation came at a cost, the great sacrifice in time and additional labour of the artisan. His attention had shifted from the commodity to the labour. The chronometermaker industrialist began to engage in political economy.

When Dent gave lectures at prestigious societies on his research, but also on the construction of watches and chronometers, his style was theatrical. While he spoke, an assistant armed with a long pole would point out the figures and letters on his diagrams, 'after the manner of the ancient actors in which a person behind the scenes spoke the part while another in front with a mask on acted the part or rather suited the action to the words'. ${ }^{81}$ The denouement came when Dent would take a watch with a compensation-balance and pull it apart, examining each piece before the audience, dividing them into groups, and listing the number of different trades each required, and the range of operations the raw materials had undergone to reach the finished piece, (see Table 1). ${ }^{82}$ As he did so, he listed the necessary parts and divisions of his total factory. In Dent's demonstration, the watch became his factory, Somerset Wharf, in miniature, and, through the deconstruction and data tables, he performed the new analytical methods of the emergent science of political economy. Combining careful, mechanical quantification with public spectacle, Dent sought to intervene in the regulation of the fiscal state.

In the audience of one such lecture, given in 1837, the eminent American engineer and mathematics professor Joseph Henry noted in his diary that Dent 'illustrates the great division of labour which is required to produce cheap and good articles where the labour saving machine is not used or cannot at present be applied' ${ }^{83}$ When Dent acquired the factory at Somerset Wharf three years later, he brought all the divisions under one roof around such enormous labour saving machines. In private, Dent noted to Henry and his companion, the surveyor Alexander Dallas Bache, that the springs worked exceptionally well, but that different materials take different times to acquire permanent elasticity. The springs took too long and in that time good capital was locked up in the manufactory. ${ }^{84}$ For Dent, it was only the level of the wage, raised by the high price of corn, which prevented English watches and chronometers from dominating home and international markets; and it was above all the exquisite temperature compensation of his chronometers that would enable British

\footnotetext{
${ }^{80}$ Edward Dent, An abstract from two lectures on the construction and management of chronometers, watches and clocks delivered before the members of the United Service Institution, May 1841, (Published by the Author, 1841), p.7.

${ }^{81}$ Joseph Henry, 7 April 1837 in January 1836-December 1837, The Princeton Years, Vol. III in Nathan Reingold (ed), The Papers of Joseph Henry, (Smithsonian Institution Press, 1979), pp. 241-3.

${ }^{82}$ Report on Mr Dent's Lecture, 'Watch statistics' in Magazine of Popular Science, 3, (1837), p.316.

${ }^{83}$ Henry, January 1836-December 1837, The Princeton Years, pp. 241-3.

${ }^{84}$ Alexander Dallas Bache, 6 April 1837, January 1836-December 1837, The

Princeton Years, p.237.
} 
manufactures to dominate without protections. Joining the clamour of capitalists, he argued for free trade and the repeal of the corn laws. ${ }^{85}$

\begin{tabular}{|c|c|c|}
\hline No. of Parts & No. of Pieces & $\begin{array}{l}\text { Trades } \\
\text { employed }\end{array}$ \\
\hline 1. Pillars & 4 & 1 \\
\hline 2. Frame & 4 & 1 \\
\hline 3. Cock and Potence & 2 & 1 \\
\hline 4. Barrell and Arbor & 3 & 1 \\
\hline 5. Going-Fuzee & 14 & 2 \\
\hline 6. Wheels & 4 & 1 \\
\hline 7. Pinions & 4 & 2 \\
\hline 8. Stop-Stud & 1 & 1 \\
\hline 9. Stop and Spring & 3 & 1 \\
\hline 10. Click and Ratchet & 3 & 1 \\
\hline 11. Motion & 16 & 2 \\
\hline 12. Jewels (5 Holes) & 28 & 2 \\
\hline 13. Cap & 3 & 2 \\
\hline 14. Dial & 5 & 3 \\
\hline 15. Index & 1 & 1 \\
\hline 16. Escapement & 13 & 3 \\
\hline 17. Compensation-Balance & 9 & 1 \\
\hline 18. Case & 3 & 1 \\
\hline 19. Pendant & 2 & 1 \\
\hline 20. Case-Joint & 6 & 1 \\
\hline 21. Case-Spring, \&c. & 4 & 2 \\
\hline 22. Main-Spring & 1 & 2 \\
\hline 23. Chain & 826 & 3 \\
\hline 24. Hands & 3 & 1 \\
\hline 25. Glass & 1 & 1 \\
\hline \multirow[t]{5}{*}{ Total of Pieces } & 992 & \\
\hline & Engine Turner & 1 \\
\hline & Engraver & 1 \\
\hline & Gilder & 1 \\
\hline & Examiner & 1 \\
\hline $\begin{array}{l}\text { Total of kinds of } \\
\text { Artificers employed }\end{array}$ & & 43 \\
\hline
\end{tabular}

Table 1. 'On the Construction of Watches and Chronometers' table transcribed from 'Report on Mr Dent's Lecture', (note 82).

In early February 1842, Dent wrote to Airy with a tentative proposal for an improved solution to temperature compensation; which he termed 'secondary continuous compensation' that would move the ordinary compensation weights on a change of temperature, in a direction nearly concentric with the centre of motion and so minimise variations in the isochronism of the system. He described a constant sliding scale approach to temperature fluctuations. The problem was a complicated one because of the marked difference between the effects of temperature change on the

${ }^{85}$ Dent, An abstract for two lectures, (note 80 ) 
inertia of the balance and the tension of the spring. There were just too many variables. Dent reckoned if he could remove the variable of the balance's changing inertia, the result of its expansion, then he could make the action of balance and spring. And he reckoned he could remove this variable by the substitution of metal with glass in the balance. ${ }^{86}$ This rested on the assumption that any expansion in the glass was negligible and so could be safely ignored. ${ }^{87}$ It was an assumption that itself rested on the long institutional and collective memory of Dent's community and their relationship with the project on surveys of national territories.

In 1753, concerned with the building of temperature-compensated pendulums for precision clocks, the eminent civil engineer John Smeaton published a description of a new pyrometer to establish precise coefficients for different materials' expansion. One of the findings of Smeaton's research was the minimal expansion of glass tubes. $^{88}$ Thirty years on, as William Roy, head of the Ordnance Survey, laid out the base line for the survey of England using steel chains constructed on the principle of a watch chain, and subjected to constant temperature measures, a captain in the Horse Guards directed him to Smeaton's measurements. Struck by Smeaton's results, Roy chose to calibrate the watch-chain survey lengths with standardised glass tubes made at a Fleet Street glassworks. ${ }^{89}$ When Roy published the account of the survey in the Philosophical Transactions, the glass tubes were painstakingly illustrated, showing the horizontal stems of thermometers whose bulbs hung inside, close to the tubes. ${ }^{90}$ Roy's surveys set the pattern: survey lengths were typically calibrated against glass tubes,${ }^{91}$ British surveys based their authority on Smeaton's pendulum compensation measurements.

It was a relationship that worked both ways, as shown by the astronomer and stockbroker Francis Baily's work on the mercurial compensation pendulum, published in 1823. Baily's table (Table 2) is dominated by the results of precision expansion measurements by surveyors and those engaged in the review of standards for surveys, both in France and Britain. ${ }^{92}$ The precedents mattered to Dent, who wrote to Airy explaining that - for his secondary compensation research - '...I refer for all the dilatations to Mr Baily's table'. ${ }^{93}$ Thanks to the British Museum's analysis, we

\footnotetext{
${ }^{86}$ Edward John Dent to George Biddell Airy, 5 February 1842, CUL, RGO 6, 585.

${ }^{87}$ Edward John Dent to George Biddell Airy, 5 February 1842, CUL, RGO 6, 585.

${ }^{88}$ John Smeaton, Description of a New Pyrometer with a Table of Experiments Made Therewith, By Mr J Smeaton, F.R.S, Philosophical Transactions, 48, (1753-1754), 598-613, Tables I and II.

${ }^{89}$ Anita McConnell, Jesse Ramsden (1735-1800) London's leading scientific instrument maker, (Aldershot, UK: Ashgate, 2007), pp.194-200.

${ }^{90}$ Jim Bennett, Plates from Royal Society Publications: illustrating William Roy's baseline on Hounslow Heath, Notes and Records of the Royal Society, 60, (2006), 225-30.

${ }^{91}$ For example: William Mudge, An account of the operations carried on for accomplishing a trigonometrical survey of England and Wales, Vol II, (London: Bulmer and co. 1801), pp.51-68; George Biddell Airy, An account of the construction of the New National Standard of Length, and of its Principal Copies, Philosophical Transactions, Vol 147, (1857), 621-702, p.640.

${ }^{92}$ Francis Baily, On the Mercurial Compensation Pendulum, Read May 9 and June 13 1823, Memoirs of the Royal Astronomical Society, Vol 1, Part II, (London: Baldwin, Cradock and Joy, Paternoster Row, 1825), 381-420, p.416.

${ }^{93}$ Edward Dent to George Biddell Airy, 21 February 1843, CUL, RGO 6, 585.
} 
now know that Dent's springs contain a remarkably high lead content, while the balance does not. For the expansion of the high lead spring, Dent referred to the results of Lavoisier and Laplace, thermometry advanced in the review of French standard measures for surveys. ${ }^{94}$ However, it is Dent's reference for the expansion of the glass balance that is most significant - kelp glass, with no lead, entirely unlike the balance spring - it was defined using Roy's 1785 survey results. Dent's glass balance was calibrated against the base line of the Ordnance Survey of Britain.

On 27 August 1836, engineering officer Robert Kearseley Dawson was tasked with organising the tithe survey of England and Wales following the Commutation of Tithes Act that year. Immediately after his secondment to the duty, Dawson began to push for a tithe survey based on, and as an opportunity to develop, the Ordnance Survey. In the same months as Dawson proposed and lobbied for a tithe survey extension of the existing Ordnance Survey, Dent was commissioned to continue his glass researches by Beaufort and Airy, respectively Supervisor and Advisor to the Division of Counties for the Parliamentary Boundary Commission, upon which commutation calculations were to be based. In these same months, Dent made the glass balance disc component of 1976,0202.69, now held by the British Museum, the expansion of which was calibrated against the base line of the Ordnance Survey of Britain. The state production of tithe maps originated as a technical point over their specification, but so inextricably entangled with political interests, the technical point fast became the stuff of ferocious debate. As a result of these interests, tithe maps were ultimately obtained from unsupervised private surveyors, who were then required to submit their work for official examination. ${ }^{95}$ Nonetheless, in 1836, while Dent was given official encouragement, the explicit and vocal intention was that tithe maps should be an extension of the Ordnance Survey; and in subsequent years the Ordnance maps became the standard of accuracy against which the private tithe maps were judged.

The relation between these surveys of standards in Baily's table (Table 2), the Ordnance, and the Tithe Commission, was timely: in the wake of the 1834 fire that destroyed the Houses of Parliament and the national standards of length, standard measures were under intense scrutiny, not least by Airy. The problem was whether those hallowed and singular Parliamentary standards, once the embodiments of national metrology, now destroyed, could ever be recovered. ${ }^{96}$ Just as he applied mechanisms of factory discipline in the construction of his clock mechanisms, Dent's patron Airy saw these questions of standards maintenance and mechanical measures as applicable and general throughout the national economy. And he was far from the alone. The Age of Reform saw a drive to bring factory and political economies into

${ }^{94}$ Andrew Ure, A Dictionary of Chemistry and Mineralogy, with their applications, Vol 1, $4^{\text {th }}$ ed, (London: Thomas Tegg \& Son, 1835), p.270.

95 Roger Kain, and Hugh Prince, The Tithe Surveys of England and Wales, (Cambridge University Press, 1985), pp.69-119, 128.

${ }^{96}$ Heinrich Christian Schumacher, A comparison of the late imperial standard Troy Pound Weight with a Platina Copy of the Same and with other Standards of Authority, Philosophical Transactions, 126, (1836), 457-94; Airy, Account of the Construction of the New National Standard of Length, (note 91); George Biddell, Airy, Autobiography of Sir George Biddell Airy, (Cambridge: Cambridge University Press, 1896); Simon Schaffer, Metrology, Metrication, and Victorian Values, Bernard Lightman (ed), Victorian Science in Context, (University of Chicago Press, 1997), pp. 438-74, 443-59. 
correspondence, and standards and tax as the principal means to this end. ${ }^{97}$ Survey measures and national politics were not just connected for reasons of patriotism, they were the means of this correspondence. ${ }^{98}$

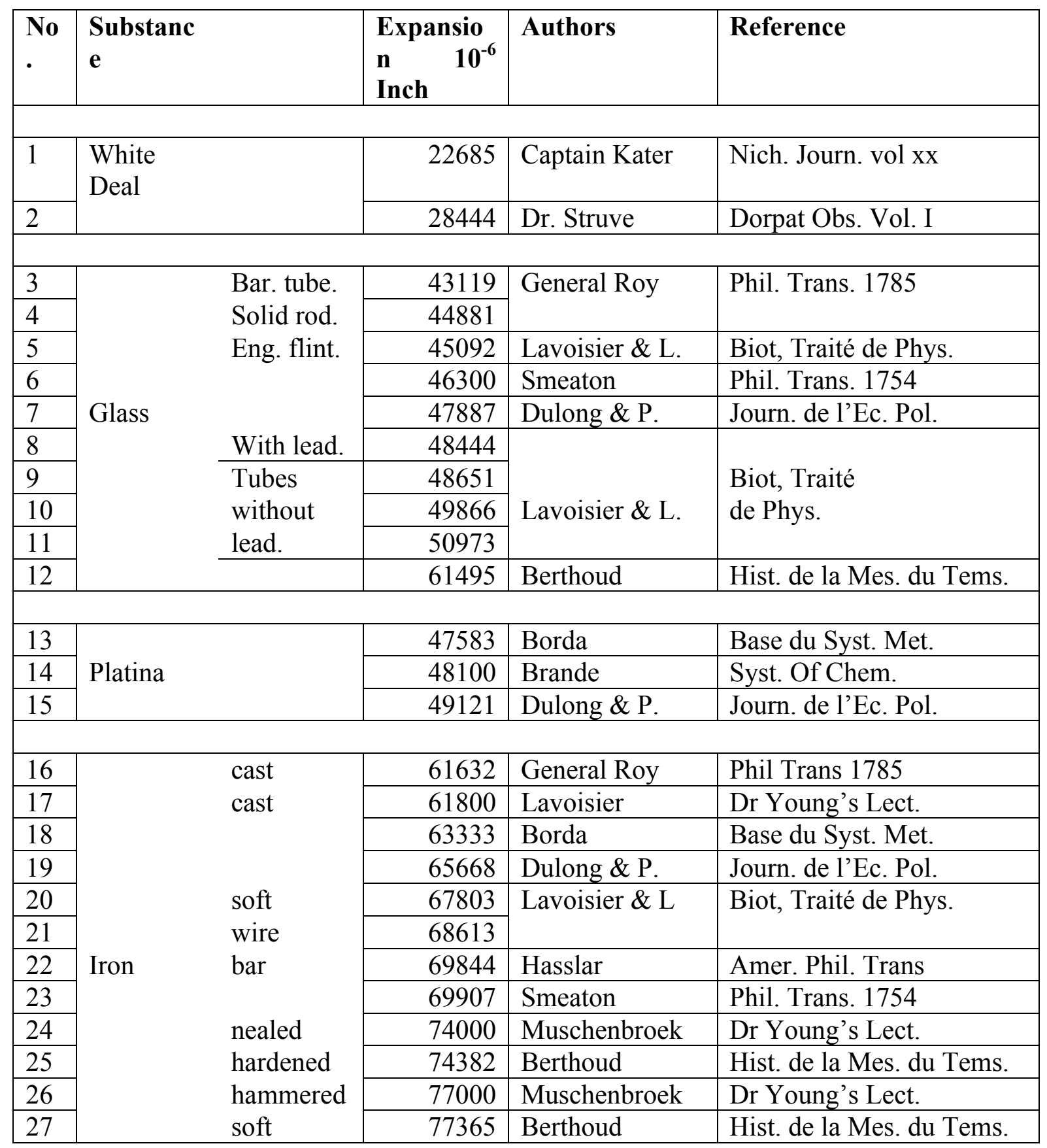

Table 2. 'Linear Expansion of various substances for one degree of Farenheit's Thermometer', table and errata transcribed from Baily, On the Mercurial Compensation Pendulum, (note 92).

97 Aashish Velkar, Markets and Measurements in Nineteenth-Century Britain, (Cambridge: Cambridge University Press, 2012), pp.1-28.

${ }_{98}$ Boyd Hilton, The Age of Atonement: The Influence of Evangelicalism on Social and Economic Thought, 1785-1865, (Clarendon Press: Oxford, 1986), 73-251; see, for example, Edward Tatham, A letter to Lord Grenville on the Metallic Standard, Oxford, 1820. 
As was noted, briefly, in 1832 Airy had acted as advisor to Parliament and the Ordnance Survey on the mathematics of the Division of Counties for the commutation of tithes. ${ }^{99}$ The transmutation of the traditional worth of farmland into hard cash mobilised vast surveys that would make land evaluation possible and credible, surveys based on lengths calibrated against the expansion of glass. For industrialists, the closely-linked repeal of the Corn Laws, regulations which not only set the value of commuted tithes but kept the price of bread artificially high by heavy duty on imports, justified a reduction in the wages of factory workers; ${ }^{100}$ wages that were Dent's particular concern with the manufacture of mechanical temperature compensation in his own factories. ${ }^{101}$ These half penny tokens, ${ }^{102}$ (Figure 11), produced round the corner from Dent's factory and workshops, are eloquent on the connexion between waged labour and the corn laws. Since the 1780s, Britain had suffered from a crisis in small change, there simply was not enough in circulation to pay the rapidly increasing proportion of the population on pitiful factory wages. In response, industrialists began producing their own trade tokens, often with moral and political slogans. ${ }^{103}$ The promise of the free trade industrialists was that with the repeal of the Corn Laws, bread - here symbolised by the wheat - would be cheap and plentiful. Their motivation was the further reduction of the pittance wages. ${ }^{104}$

${ }^{99}$ Division of Counties, Hansard Manuscripts, HC Deb, 6 February 1832 vol 10 cc417-21.

${ }^{100}$ Karl Marx, Capital, Volume I, (London: Lawrence \& Wishart, 1974), pp. 264-80.

${ }^{101}$ Dent, An abstract from two lectures... p.7.

102 David Thornbury Batty, Batty's catalogue of the copper coinage of Great Britain, (J. Forsyth, Manchester, 1868), p.560.

${ }^{103}$ Richard Doty, The Soho Mint and the Industrialization of Money, (London: British Numismatic Society, 1998); Peter Mathias, 'Official and Unofficial Money in the Eighteenth Century: the evolving uses of money. The Howard Linecar Memorial Lecture', British Numismatic Journal Vol. 73, (2003), pp. 69-83; David Dykes, 'Some Reflections on Provincial Coinage, 1787-1797', British Numismatic Journal, Vol. 73, (2003), pp. 160-74. George Selgin, Good Money: Birmingham Button Makers, the Royal Mint, and the Beginnings of Modern Coinage 1775-1821, (The University of Michigan Press, 2008), p.30.

${ }^{104}$ Marx, Capital, Volume I, pp. 264-80, (note 100). 


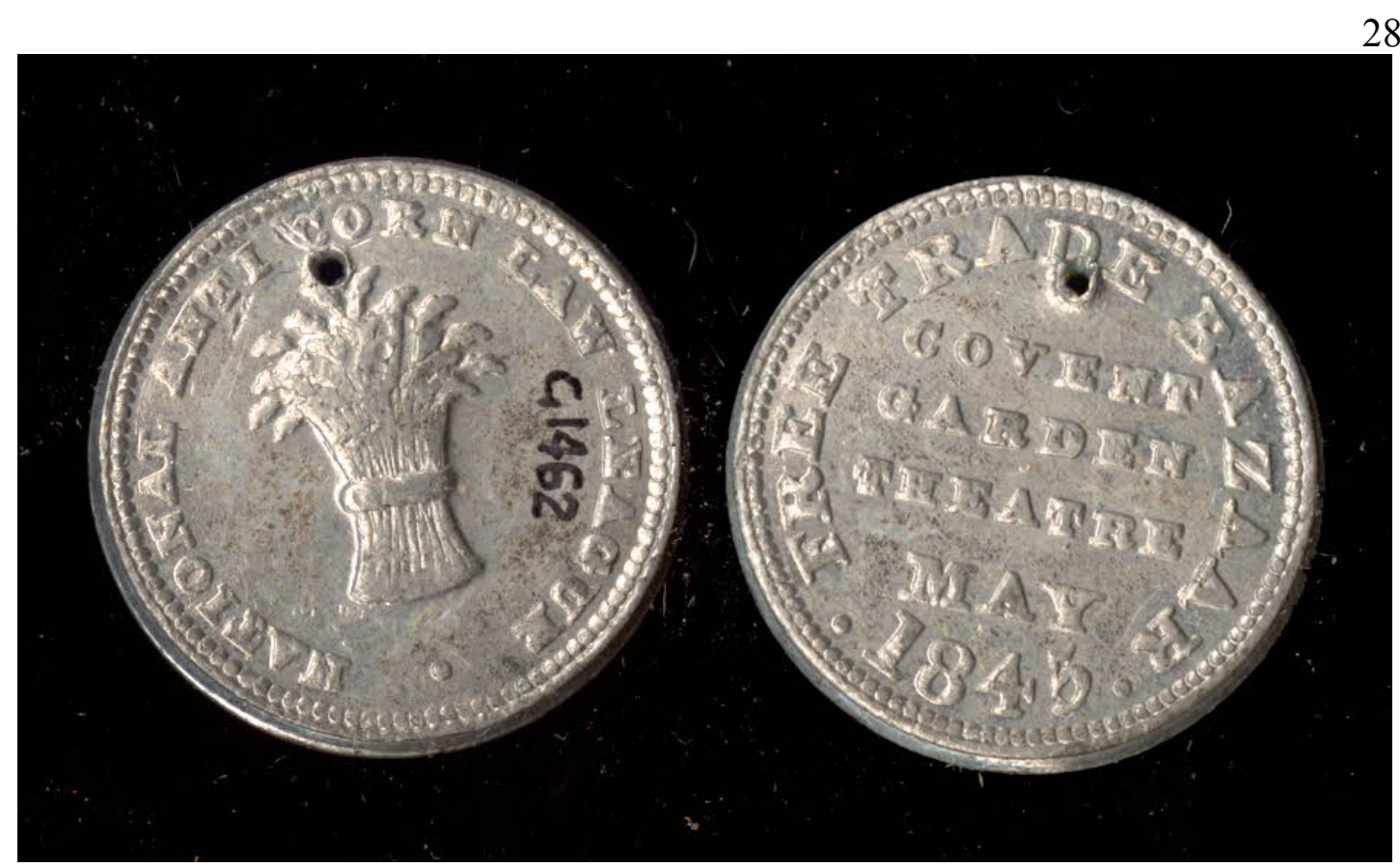

Figure 11. Anti Corn Law League tokens, inscription reverse: NATIONAL ANTI CORN LAW LEAGUE around sheaf of wheat; obverse: FREE TRADE BAZAAR COVENT GARDEN THEATRE MAY 1845. Tokens made of white metal in 1845 in commemoration of the Free Trade Bazaar. The tokens have been pierced for suspension as medals, British Museum MG1462. The Trustees of the British Museum, (CC BY-NC-SA 4.0).

The connexions between the regulation of clocks and of the national market were explicit. In February 1842 Airy and Dent corresponded almost daily on the design of Dent's proposed mechanical system of secondary continuous temperature compensation, founded on his calibration against the material compensation of glass. ${ }^{105}$ In the middle of this flurry of correspondence, Airy wrote to the editor of political weekly, The Examiner, proposing a solution to the problem of the Corn Laws. Significantly, Airy described the 'great machine of the corn-market' as a chronometer gaining and losing in rate with temperature. The astronomer argued that:

...the uniformity of movement of any machine is to be secured... not by accelerating it when moving most slowly, and retarding it when moving most quickly, but by accelerating it when losing speed and retarding it when gaining speed, that the motion is rendered more uniform than it would be without interference... ${ }^{106}$

The solution Airy proposed to the problem of corn rates was to take a fixed duty based on an average price, the primary compensation, and add or subtract from this sum based on the past two averages of price, the secondary compensation. The result: a continuous sliding scale. Airy applied the solution of secondary temperature compensation to the corn-market. For others at the vanguard of reform, like politician and, in the 1820s, President of the Board of Trade, William Huskisson, it was specifically the clockwork action of the steam engine governor device that provided the model regulation of the fiscal state, such that,

$[t]$ he Bank would be the great steam engine of the State to keep the channel of circulation always pressing full, and the power of converting its notes at any

\footnotetext{
${ }^{105}$ George Biddell Airy and Edward John Dent, correspondence, February 1842, CUL, RGO, 6, 585.

${ }^{106}$ George Biddell Airy to Albany Fonblanque, 14 February 1842, CUL RGO 6427.
} 
time into gold bullion at $78 \mathrm{~s}$ the ounce the regulator and index of the engine, by which the extent of its operations and the sufficiency of the supply would be determined and ascertained. ${ }^{107}$

For Airy and his contemporaries it was as if getting the Corn Laws right demanded the same techniques as getting precision timepieces to work properly.

Characteristically of Airy, and indeed of Dent, the solution he preferred was a mechanical one. ${ }^{108}$ The driving force of their collaborations was to remove reliance on human care and any dependency on the talent and ability of the workman. ${ }^{109}$ This was the principal criterion in their assessment of mechanisms. Dent went so far as to write to Airy in September 1842, '....while I consider the principle perfect and capable of being made by a careful workman still I am of the opinion that it must more or less depend on his practical care and experience of which $I$ have a great dread...' [emphasis Dent's own]. A mechanical solution might perhaps obviate the fundamental fear of the two managers - overdependence on skilled labour. Obsessed with the cost of labour, Dent acted as a political economist, deploying tabulation and automation to intervene in the labour market.

In the summer of 1842, just a few months on from Airy's letter to The Examiner and following their correspondence on temperature compensation, Dent began to consider its application in the construction of a new clock for the Royal Exchange. This building was the edifice of commutation, and its clock was to be a finely compensated pendulum, rated against a good pocket chronometer. On its completion in 1845 and in consideration of the construction of a new clock for the Houses of Parliament, Airy wrote,

I shall state, without Hesitation, that I believe the Clock you have constructed for the Royal Exchange to be the best in the world, as regards Accuracy of Going and Striking, and that I consider you the most proper Person to be entrusted with the Construction of another Clock of Similar Pretensions. ${ }^{110}$

The Factory Act of 7 June 1844 stated that the hours of work indicated by the factory clock must be regulated by a public clock. ${ }^{111}$ When, in 1853, Frederick Dent (né Rippon) took on his step-father's name and the contract to construct the great Westminster clock, he wrote to the Southwark MP Sir William Molesworth, a free trader and vocal proponent of tithe commutation, now vying for the position of colonial secretary. To Molesworth, Dent explained the nature of the his commission for 'the great clock, which is to be the standard of time for London, and is to have a galvanic communication with the Royal Observatory, to report its own performance

${ }^{107}$ William Huskisson, 1818, 'Rough draft on coin and currency', Huskisson Papers, British Library, Add. MS 38741, fos. 242-52.

${ }^{108}$ For Airy see, in particular, Simon Schaffer, Astronomer's Mark Time: Discipline and the Personal Equation, Science in Context, Vol. 2 Iss. 1, (1988), 115-45. For Dent see Edward John Dent to George Biddell Airy, 28 October 1841; 17 August 1842; 26 September 1842, CUL, RGO, 6, 585.

${ }^{109}$ See, for example, Edward John Dent to George Biddell Airy, 28 October 1841; 17 August 1842; 26 September 1842, CUL, RGO, 6, 585

${ }^{110}$ George Biddell Airy to Edward John Dent, 22 July 1845, in Anon, A Portion of the Papers relating to the Great Clock at the New Palace at Westminster, (London: Printed by William Clowes and Sons, 1848), p.11.

${ }^{111}$ Marx, Capital, Volume I, p.268, (note 100). 
to the Astronomer Royal daily. ${ }^{112}$ Built to be the most accurate public clocks in the world, ${ }^{113}$ where that accuracy was a function of Dent's secondary compensation calibrated against the expansion of the glass balance, ${ }^{114}$ Dent's Great Clocks were constructed to set the standard for the regulation of factory hours. ${ }^{115}$

These hours were the constant struggle between the worker and the capitalist, the factory manager, who by 'nibbling and cribbling' at minutes and seconds, stole from the wage value of the labour expended. ${ }^{116}$ Cruikshank didn't restrict himself to drawing Cinderella and other fairy stories: he also famously satirised how industrialists exploited the Factory Acts and time discipline to lower wages yet further, wasting bodies to the virtue of competitive pricing. ${ }^{117}$ The image (Figure 12) shows the sweating system, where, if the output of the seamstress fell below the average rate, she was dismissed, and if she kept pace, she herself would be ground into the production process. ${ }^{118}$ Of the sweaters, "Government contract work is the worst of all, and the starved-out and sweated-out tailor's last resource' [original emphases]. ${ }^{119}$ The government was the biggest capitalist of all, and in the Age of Reform it was the government that sustained regulation of the capitalist economy.

${ }^{112}$ Frederick (Rippon) Dent to Sir William Molesworth, 22 September 1853, Westminster New Palace. Copies of all papers and correspondence relating to the great clock and bells for the new Palace at Westminster (in continuation of Parliamentary Paper, no. 500, of session 1852), Vol. 53, (House of Commons Papers, 1854-5), p. 13.

${ }^{113}$ George Biddell Airy and Edward John Dent, 22 July 1845, in Anon, A Portion of the Paper, p.11, (note 110).

${ }^{114}$ George Biddell Airy to Edward John Dent, correspondence, February 1842, CUL, RGO, 6, 585.

${ }^{115}$ Frederick (Rippon) Dent to Sir William Molesworth, 22 September 1853, 1854-5, Westminster New Palace. Copies of all papers and correspondence relating to the great clock and bells for the new Palace at Westminster (in continuation of Parliamentary Paper, no. 500, of session 1852), House of Commons Papers, Vol. 53, p. 13.

${ }_{116}$ Marx, Capital, Volume I, p.232 (note 100).

${ }^{117}$ Robert L. Patten, George Cruikshank's life, times, and art, 1835-78, Vol. II, (London: Lutterworth, 1992-6).

${ }_{118}$ Marx, Capital, Volume I, pp.518-9, (note 100).

${ }^{119}$ Charles Kingsley, Cheap Clothes and Nasty, by Parson Lot, (London: William Pickering, 1850). 


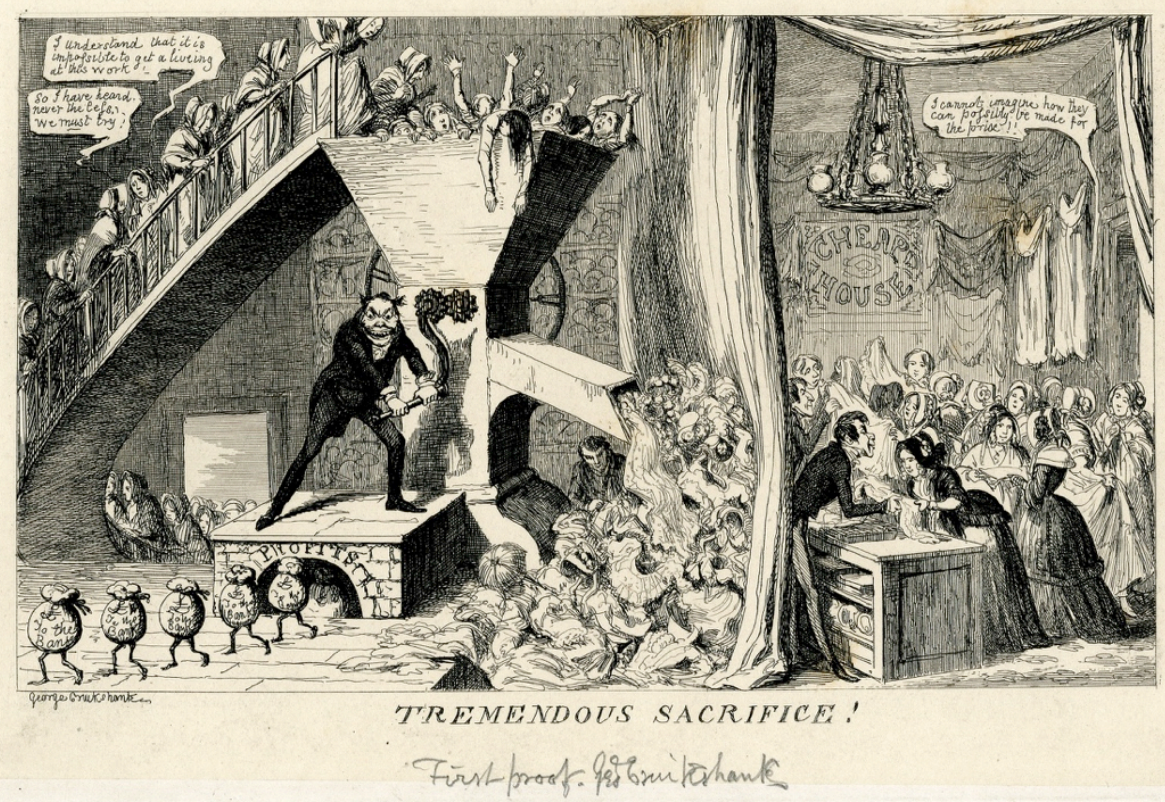

Figure 12. George Cruikshank, Tremendous Sacrifice!, 1847, Our Own Times (London: Bradbury \& Co, 1846). British Museum 1978,U.2834. The Trustees of the British Museum, (CC BY-NC-SA 4.0).

Dent's work on the Royal Exchange clock coincided with his finalisation of the patent for his secondary compensation, and he wrote to Airy noting that this would be the last public scientific work he would engage in, 'as my future life will be devoted to the practical introduction of my improvements. ${ }^{120}$ Eoin Phillips' work has shown in the cases of Frodsham versus Parkinson, and French versus Muston, fierce disputes over who counted as an owner, or inventor, or workman, that the concentration of capital in larger manufactories, as in the case of Dent, goes along with the work of standardisation. ${ }^{121}$ Dent could not have made a more extensive introduction of his improvements than in the construction of the Royal Exchange and subsequently Big Ben, intended to be the public face of Greenwich standard time, explicitly built to give the standard of time for London, commerce and manufacture.

The reality of the Westminster clock was far from the ambitions of its makers and designers. In addition to the pendulum compensation, the going rate had to be further regulated by the adding or taking away of copper coins, ${ }^{122}$ the small change of pittance wages acting as literal pennyweights (Figure 13). The great clock took a tax to be regulated. Standards are enacted through representation, a social process of agreement within a community, which in turn defines the community, to elect an agent that will speak on their behalf. The faulty-going of Parliament's clock required constant correction, judged against glass-calibrated chronometers, and regulated by

\footnotetext{
${ }^{120}$ Edward John Dent to George Biddell Airy, 29 October 1842, RGO 6574 .

${ }^{121}$ Phillips, Making time fit.

${ }^{122}$ Chris McKay, Big Ben: The Great Clock and the Bells at the Palace of Westminster, (Oxford University Press, 2010), see 'Foreword by Mike McCann' and pp.17, 205, 267.
} 
the small denomination currency of wage-labour. ${ }^{123}$ This standard did not embody some abstract notion of precision, but rather a social contract, ${ }^{124}$ coupling contemporary questions into Corn Laws and tithe commutations, with factory acts and labour legislation; in short, free trade and intense state regulation. ${ }^{125}$ These were its referents. Not in spite of all its deficiencies, but rather because of them, Big Ben defined Britain's capital. Performing its own greatest satire, the clock of capital demanded to be paid (Figure 13).

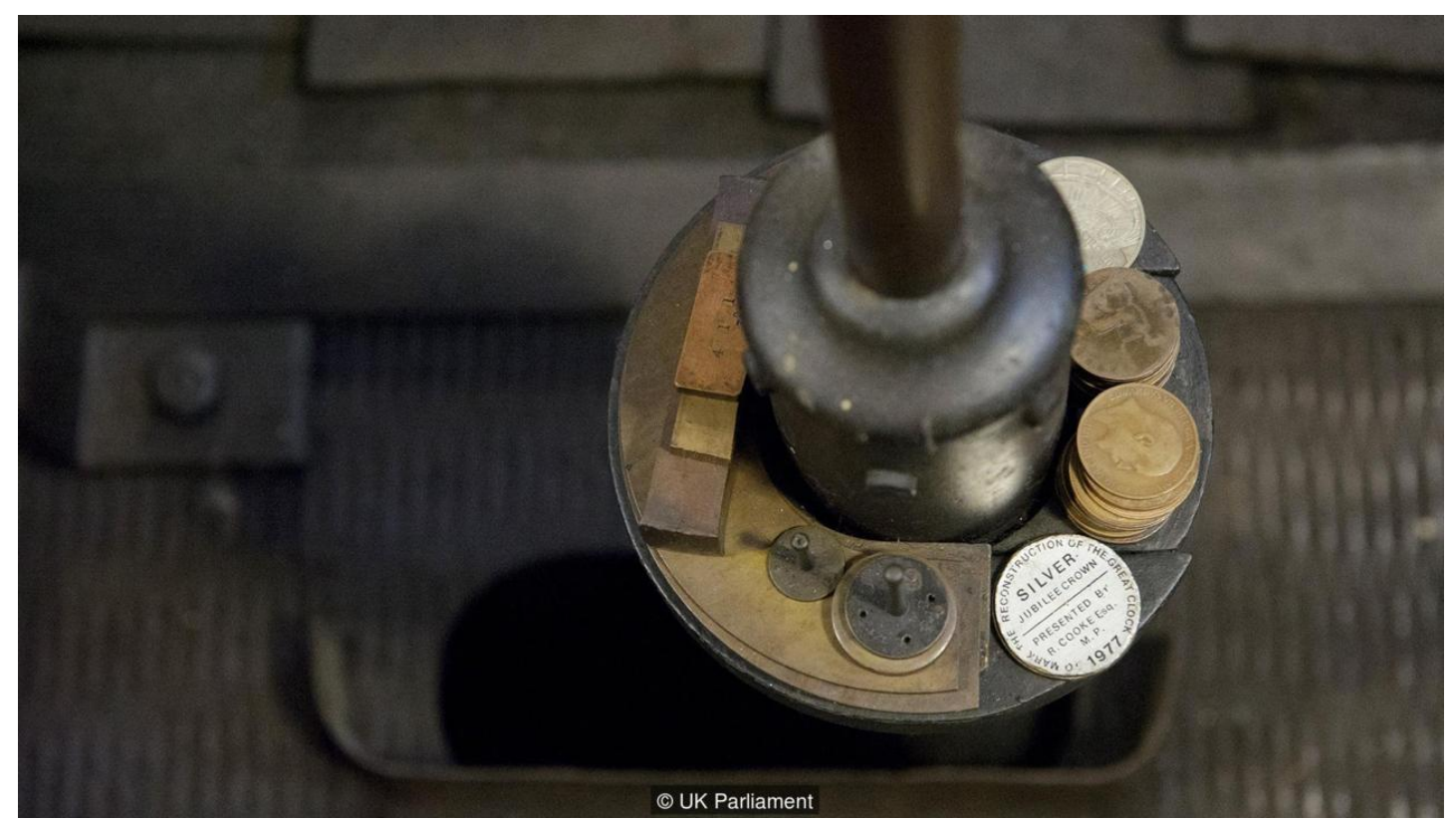

Figure 13. The pennies used to regulate Big Ben's going rate, with one penny producing a gain of approximately two fifths of a second in 24 hours. Copyright: UK Parliament.

\section{Conclusion}

Three questions were set out at the beginning of this paper: the Frodsham argument that if Dent's glass springs performed so well, one must ask why there was only one of them; the Denison argument that according to Dent, the springs did indeed work exceptionally well, but the workmen would not; and the query that emerges from Dent and Denison's defence: how was it that glass springs, which gained in rate, could constitute superior performance? This conclusion looks to propose answers to each, before developing the significance of these answers in the context of the paper as a whole.

First, Dent's glass was not singular because it was a failure; it was singular because standards function by the comparison of one against many. Dent's glass was an embodied standard, as much as the Parliamentary standard yard length enclosed in a glass case and embedded at Big Ben in the masonry of Westminster. Like the Parliamentary standards, Dent's glass was authoritative precisely through its removal

${ }^{123}$ Doty, The Soho Mint, (note 103); Mathias, 'Official and Unofficial Money' (note 103); Dykes, 'Some Reflections on Provincial Coinage,' (note 103); Selgin, Good Money, p.30, (note 103).

${ }^{124}$ Schaffer, 'Metrology, Metrication, and Victorian Values.' (note 96).

${ }^{125}$ William Ashworth, The Industrial Revolution: The state, knowledge and global trade, (London: Bloomsbury Academic, 2017), pp.129-144; 221-42. 
from circulation. Such embodied standards set masters apart from the workmen by judging the workmanship of many against the single material form. Second, when Dent noted the workmen would not work the glass, he was recalling less their recalcitrance than his own confessed dread of dependence on skilled work. For Dent, the threat of such skill was fatally to increase the cost of work. His ambition was always to find a resource whose substitution would render production reliable, cheap, and efficient - that is to say, profitable. Glass, so it seemed, might offer just such a substitution. Not only this, but precisely because of the long history of intense and oppressive glass excise, it was the quantified material par excellence: glass was the material of political economy, the new science of labour extraction. In his design of timepieces, Dent used glass substitutions, and the authority of national surveys, to assume he could neglect balance inertia and so remove a troublesome variable. Similarly, it seemed to Dent, the substitution of glass might do away with dependence on the labour of skilled workman: the troublesome variable of his political economy. This dread of human error shared by Airy and Dent was exemplary of the age. It underpins the third, and final question: how was it that glass springs, which gained in rate, could constitute superior performance. The answer: precisely because glass that gained, without variation, could be subjected to constant and invariable correction. Dent's glass was a material of continuous reform, and embodied the ideals of the reforming machine age as surely as Airy's solution to the corn-market; or a factory tell-tale secreted in a chronometer mechanism.

Some review of these essential points is helpful. The Corn Laws set the rate of factory wages and the rate of tithes commuted into cash. When Dent became a factory owner, he joined free trade industrialists in fighting for the repeal of the Corn Laws. But, while he argued for the removal of one set of regulations, calibration by glass placed Dent and his chronometry at the heart of the new emerging order. Technical analysis has revealed that the glass balance differed from the high lead content spring: it was a kelp glass with no lead in it at all. Unlike the spring, the balance shared the composition of the glass rods used by William Roy to measure the baseline of the great trigonometric survey of England, and by Ordnance surveyors that came after Roy. Dent's glass balance was calibrated against the glass rods from the great surveys that were themselves used to calculate tithes. His precision compensated timekeepers were calibrated against the glass balance. And in turn these timekeepers calibrated the Great Clocks, the most public of state standards, which set the standard for working hours in Britain.

By contrast, the high lead content of Dent's springs reflected the high duty of the most oppressively regulated manufacture. There were two in the British Museum collection, one fitted to a balance and trialled, 1976,0202.69 (Figure 2(a)); the other perfect and unused, 1958,1006.3009, (Figure 2(b)). Digital microscopy has revealed the trialled spring to be thicker and flatter (Figure 3(a) and Figure 4(a), the unused spring rounded and fine (Figure 3(b) and Figure 4(b)). When Dent spoke of his glass springs to Joseph Henry he noted they were not like steel springs, but thicker and flatter. The purpose of the unused spring, with its fine round form, was never to be a demonstration model of those being trialled, its purpose was to look exactly like a steel spring, but perfectly rendered in luminous glass. Its purpose was social and symbolic, a nineteenth century attribute of innovative art. Unlike the balance and spring of 1976,0202.69, and indeed the 1958,1006.3073 Scrymgeour spring, analysis of 1958,1006.3009 shows potassium coating its surface (Figure 10, blue trace for $1958,1006.3009$ showing spike at $\mathrm{K}$ spectra). Were this a result of the production process it should appear in 1976,0202.69 and 1958,1006.3073, yet neither exhibit any 
such trace. The surface of 1958,1006.3009 is coated in potassium from the fingers that have held it out to be admired. This spring played the greatest role of all in the corn-market chronometer.

On 14 February 1845, while Dent applied for the commission to manufacture Big Ben, Prime Minister Sir Robert Peel addressed the House of Commons, on the subject of the repeal of glass duty. It is hard to overstate the importance of this address, a total reversal in Peel's policies until that point, this financial statement was the direct precedent for the repeal of the Corn Laws the following year in 1846. Corn Law Repeal gained support not least through the explicit intention of re-organising production in South Asia to promote labour extraction and the drain of wealth. ${ }^{126}$ The British India Society was one of the Anti-Corn Law League's most notable allies, an allegiance forged significantly through the cumul des mandats of reformer, George Thompson, who sets out the ambition in 'The resources of India' section of his tract on the Corn Laws. Though in no sense total, ${ }^{127}$ nonetheless the impact of such policy reforms was significant, ${ }^{128}$ and played a crucial role in the global extension of capitalism. The repeal of the glass duty as precedent to that of the Corn Laws had weighty consequences; and for this reason Peel's words are worth reading in some detail -

... If you permit this article to be free of duty, it is difficult to foresee, in the first place, to what perfection this beautiful fabric may not be brought; and, secondly, it is impossible to say to what new purposes glass, manufactured by our own skill and capital, may not be applied. I hold in my hand the balance-spring of a chronometer, made of glass, instead of the ordinary material, steel (hear, hear!). I understand that it possesses a greater degree of elasticity, and that it has a greater power of resisting the alternations of heat and cold. The manufacture is so expensive, and it requires such skill on the part of the workman, that I do not believe, under the present system of restriction, that this exquisite discovery can be generally applied... ${ }^{129}$ [emphases author's own].

The opening section of this paper noted that glass manufacture in Britain was heavily regulated, that the history of the regulation of glass in Britain was a history of social regulation, and that the meanings of glass and tax had become synonymous. When Peel held out the glass balance spring as an attribute of innovative art, and called for the withdrawal of the duty, he drew on each of these points. But Swift's quotation in full is useful: 'Satire is a sort of glass wherein beholders do generally discover everybody's face but their own; which is the chief reason for that kind reception it meets with in the world, and that so very few are offended with it. ${ }^{130}$ Glass was a medium of social comment through distortion of the existing order. For all that calls for free trade purported to be calls for deregulation, the reality was - like Airy's

\footnotetext{
${ }^{126}$ George Thompson, Corn Laws, (Manchester: Haycraft, 1841), pp.18-20.

${ }^{127}$ Indrajit Ray, 'The Myth and Reality of deindustrialisation in early modern India', in Latika Chaudhary et al (eds) A New Economic History of Colonial India, (Routledge: London and New York, 2016), pp.52-66.

${ }^{128}$ Romesh Dutt, The Economic History of India in the Victorian Age, $3^{\text {rd }}$ ed, (London: Kegan Paul, 1908).

${ }^{129}$ Sir Robert Peel's Financial Statement, Delivered in the House of Commons on 14 February 1845, New Tariff: Tables of New Duties of Customs, (London: James Gilbert, 49 Paternoster Row, 1845).

${ }^{130}$ Swift, A tale of a tub, p. cxxviii, (note 47).
} 
solution to the repeal of the corn laws - an extreme increase in the intensity and extent of other regulatory practices, ${ }^{131}$ regulations calibrated against Dent's glass balance.

The satirical weekly, Punch; or the London Charivari responded to the financial statement with a portrait of Peel, captioned 'the man with a balance at his bankers'. Beside the portrait, a verse: 'Peel's Parliamentary Drinking Song', composed to commemorate the event, (Figure 14). The portrait and verse are reproduced here as envoi, because they so effectively illustrate the convergence of interests warranted by the manipulation and deregulation of glass. Swift's statement not only referred to a mirror - that is, silvered glass - but the inherently polysemic and satirical nature of glass culture. In Punch's verse, 'glass' was both material and drinking vessel: the many meanings of 'glass' enabled an effortless movement between duty on drink and on the vitreous material. Through such irreverent ambiguity, its long history of satire and polysemy, glass became a material that could extend a principle. In the House of Commons, Peel held out Dent's glass spring and successfully called for the repeal of the glass tax, the precedent for the 1846 repeal of the Corn Laws, a crucial episode in the global extension of capitalism. Less than a month after his address on the 'salient spring of prosperity which has supplied the void caused by the remission of taxation', Peel made metaphor, material. He held out an actual spring, Dent's spring, and the salience of the spring was glass.

${ }^{131}$ Ashworth, The Industrial Revolution, pp.129-144; 221-42, (note 125). 


\section{PEEL'S PARLIAMENTARY DRINKING SONG.}

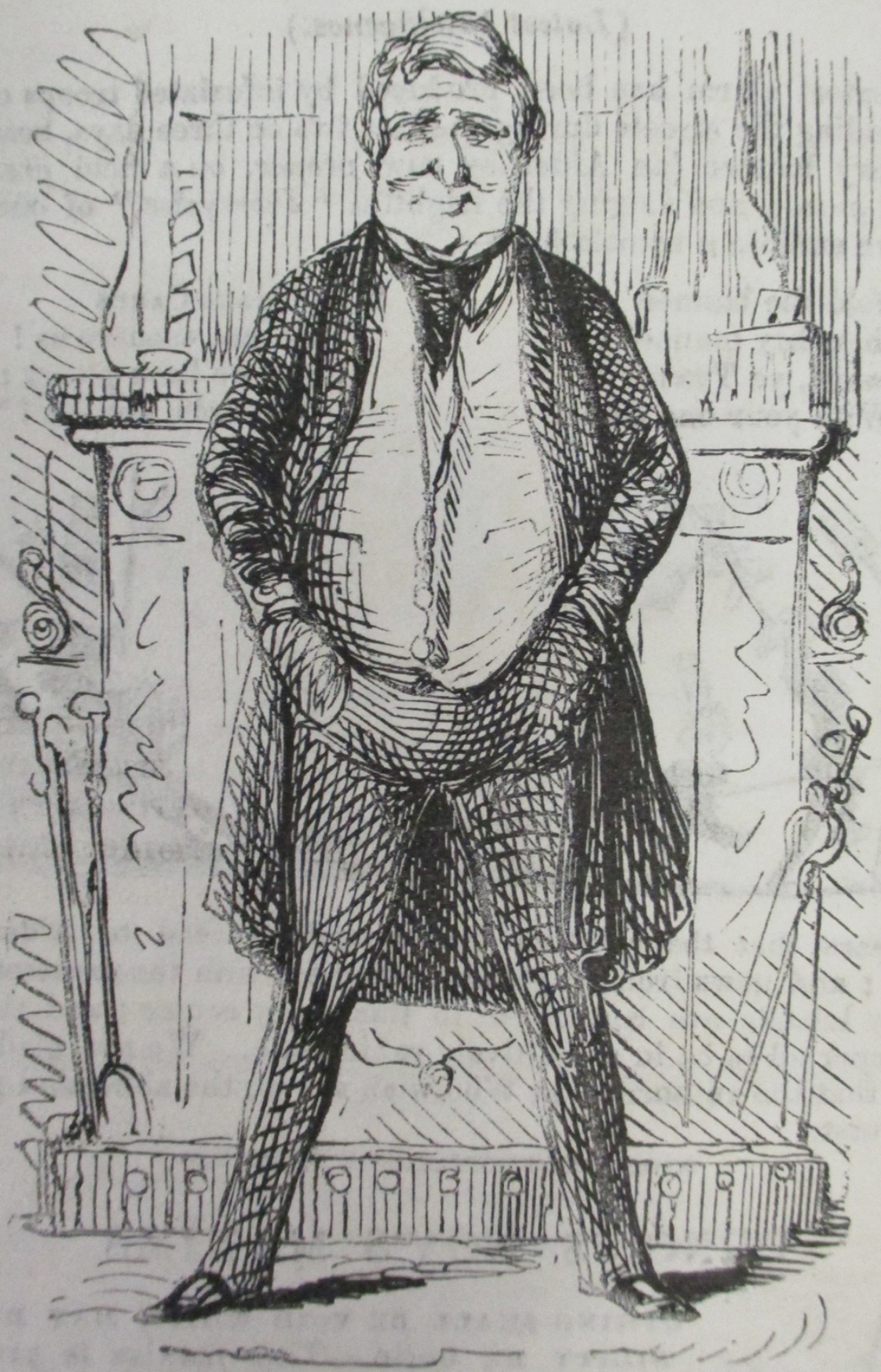

THE MAN WITH A BALANCE AT HIS BANKERS.

Figure 14. 'Peel's parliamentary drinking song' (below) and 'The man with the balance at his bankers' (above), Punch; or the London Charivari, Vol. 8, (London: Fleet Street, 1845), p.118. Private collection. 
Here's to each Tory and Radical too;

Just only my Income Tax pass, boys, And you'll see how completely JOHN BULL I shall "do".

By taking the duty off GLASS, boys.

Let the bill pass, JOHN's such an Ass

I'll warrant he'll find an excuse in the Glass.

Here's the debator whose speeches we prize,

And here's to the spouter of twaddle;

To gentlemen gifted with brains; and likewise.

To those who have none in their noddle.

Let the bill pass, JOHN's such an Ass

I'll warrant he'll find an excuse in the Glass.

Here's unto Cordon, and here's to friend BRIGHT,

The farmer's and landowner's friend, too;

To those who for Corn-Law monopoly fight

And those for Free Trade who contend, too.

Let the bill pass, JOHN's such an Ass

I'll warrant he'll find an excuse in the Glass.

Here's to all those by the Poor Law who stand,

As a piece of humane legislation;

And to those who declare it a curse to the land,

And a shame and reproach to the nation.

Let the bill pass, JOHN's such an Ass

I'll warrant he'll find an excuse in the Glass.

Here's to the FEW for class int'rests who vote,

With a view to the loaves and the fishes;

Here's to the MANY who strive to promote

Their constituents objects and wishes.

Let the bill pass, JOHN's such an Ass

I'll warrant he'll find an excuse in the Glass.

Here's to Young England and here's unto Old;

For all parties I care not a feather:

So long as you all are contented to hold,

In support of my Budget, together.

Let the bill pass, JOHN's such an Ass

I'll warrant he'll find an excuse in the Glass 